\title{
THE
}

\section{Ozone depletion events observed in the high latitude surface layer during the TOPSE aircraft program}

\author{
Brian A. Ridley \\ Brian G. Heikes \\ University of Rhode Island, bheikes@uri.edu \\ Julie A. Snow \\ University of Rhode Island \\ et al
}

Follow this and additional works at: https://digitalcommons.uri.edu/gsofacpubs

Terms of Use

All rights reserved under copyright.

\section{Citation/Publisher Attribution}

Ridley, B. A., et al., Ozone depletion events observed in the high latitude surface layer during the TOPSE aircraft program, J. Geophys. Res., 108(D4), 8356, doi: 10.1029/2001JD001507, 2003.

Available at: https://doi.org/10.1029/2001JD001507

This Article is brought to you for free and open access by the Graduate School of Oceanography at DigitalCommons@URI. It has been accepted for inclusion in Graduate School of Oceanography Faculty Publications by an authorized administrator of DigitalCommons@URI. For more information, please contact digitalcommons-group@uri.edu. 


\title{
Ozone depletion events observed in the high latitude surface layer during the TOPSE aircraft program
}

\author{
B. A. Ridley, ${ }^{1}$ E. L. Atlas, ${ }^{1}$ D. D. Montzka, ${ }^{1}$ E. V. Browell, ${ }^{2}$ C. A. Cantrell, ${ }^{1}$ D. R. Blake, ${ }^{3}$ \\ N. J. Blake, ${ }^{3}$ L. Cinquini, ${ }^{1}$ M. T. Coffey, ${ }^{1}$ L. K. Emmons, ${ }^{1}$ R. C. Cohen, ${ }^{4}$ R. J. DeYoung, ${ }^{2}$ \\ J. E. Dibb ${ }^{5}$ F. L. Eisele, ${ }^{1}$ F. M. Flocke, ${ }^{1}$ A. Fried, ${ }^{1}$ F. E. Grahek, ${ }^{1}$ W. B. Grant, ${ }^{2}$ \\ J. W. Hair, ${ }^{2}$ J. W. Hannigan, ${ }^{1}$ B. J. Heikes, ${ }^{6}$ B. L. Lefer, ${ }^{1}$ R. L. Mauldin, ${ }^{1}$ J. L. Moody, ${ }^{7}$ \\ R. E. Shetter, ${ }^{1}$ J. A. Snow, ${ }^{6}$ R. W. Talbot, ${ }^{5}$ J. A. Thornton, ${ }^{4}$ J. G. Walega, ${ }^{1}$
}

A. J. Weinheimer, ${ }^{1}$ B. P. Wert, ${ }^{1}$ and A. J. Wimmers ${ }^{7}$

Received 14 November 2001; revised 19 March 2002; accepted 2 April 2002; published 15 January 2003.

[1] During the Tropospheric Ozone Production about the Spring Equinox (TOPSE) aircraft program, ozone depletion events (ODEs) in the high latitude surface layer were investigated using lidar and in situ instruments. Flight legs of $100 \mathrm{~km}$ or longer distance were flown 32 times at $30 \mathrm{~m}$ altitude over a variety of regions north of $58^{\circ}$ between early February and late May 2000. ODEs were found on each flight over the Arctic Ocean but their occurrence was rare at more southern latitudes. However, large area events with depletion to over $2 \mathrm{~km}$ altitude in one case were found as far south as Baffin Bay and Hudson Bay and as late as 22 May. There is good evidence that these more southern events did not form in situ but were the result of export of ozone-depleted air from the surface layer of the Arctic Ocean. Surprisingly, relatively intact transport of ODEs occurred over distances of 900-2000 km and in some cases over rough terrain. Accumulation of constituents in the frozen surface over the dark winter period cannot be a strong prerequisite of ozone depletion since latitudes south of the Arctic Ocean would also experience a long dark period. Some process unique to the Arctic Ocean surface or its coastal regions remains unidentified for the release of ozone-depleting halogens. There was no correspondence between coarse surface features such as solid ice/snow, open leads, or polynyas with the occurrence of or intensity of ozone depletion over the Arctic or subarctic regions. Depletion events also occurred in the absence of long-range transport of relatively fresh "pollution" within the high latitude surface layer, at least in spring 2000. Direct measurements of halogen radicals were not made. However, the flights do provide detailed information on the vertical structure of the surface layer and, during the constant $30 \mathrm{~m}$ altitude legs, measurements of a variety of constituents including hydroxyl and peroxy radicals. A summary of the behavior of these constituents is made. The measurements were consistent with a source of formaldehyde from the snow/ice surface. Median $\mathrm{NO}_{\mathrm{x}}$ in the surface layer was 15 pptv or less, suggesting that surface emissions were substantially converted to reservoir constituents by $30 \mathrm{~m}$ altitude and that ozone production rates were small $(0.15-1.5 \mathrm{ppbv} / \mathrm{d})$ at this altitude. Peroxyacetylnitrate (PAN) was by far the major constituent of $\mathrm{NO}_{\mathrm{y}}$ in the surface layer independent of the ozone mixing ratio. INDEX TERMS: 0365 Atmospheric Composition and Structure: Tropospherecomposition and chemistry; 0368 Atmospheric Composition and Structure: Troposphere - constituent transport and chemistry; 0322 Atmospheric Composition and Structure: Constituent sources and sinks; KEYWORDS: Ozone, arctic, Surface layer, Ozone depletion, TOPSE

Citation: Ridley, B. A., et al., Ozone depletion events observed in the high latitude surface layer during the TOPSE aircraft program, J. Geophys. Res., 108(D4), 8356, doi:10.1029/2001JD001507, 2003.

\footnotetext{
${ }^{1}$ Atmospheric Chemistry Division, National Center for Atmospheric Research, Boulder, Colorado, USA.

${ }^{2}$ Atmospheric Sciences NASA Langley Research Center, Hampton, Virginia, USA. USA.

${ }^{3}$ Department of Chemistry, University of California, Irvine, California,

Copyright 2003 by the American Geophysical Union.
} 0148-0227/03/2001JD001507
${ }^{4}$ Department of Chemistry, University of California, Berkeley, California, USA.

${ }^{5}$ Institute for the Study of Earth, Oceans and Space, University of New Hampshire, Durham, New Hampshire, USA.

${ }^{6}$ Center for Atmospheric Chemical Studies, Graduate School of Oceanography, University of Rhode Island, Narragansett, Rhode Island, USA.

${ }^{7}$ Department of Environmental Sciences, University of Virginia, Charlottesville, Virginia, USA. 


\section{Introduction}

[2] Nearly 16 years ago, Oltmans and Komhyr [1986] and Bottenheim et al. [1986] reported observations of anomalously low mixing ratios of ozone in the surface layer of the Arctic at Barrow $\left(71.3^{\circ} \mathrm{N}, 156.8^{\circ} \mathrm{W}\right)$, Alaska and at Alert $\left(82.5^{\circ} \mathrm{N}, 62.3^{\circ} \mathrm{W}\right)$, Canada during late winter through spring. These events in which ozone can be reduced from typical winter mixing ratios of 25-40 ppbv to below $10 \mathrm{ppbv}$ and less frequently to below $1 \mathrm{ppbv}$ have since been observed regularly during spring [Bottenheim et al., 1990; Solberg et al., 1996; Barrie and Platt, 1997; Hopper et al., 1998]. At Alert, for example, these events last from less than a day to a week or more and have been observed as early as the first week of March, well before continuous sunlight in the Arctic, and as late as the second week of June [Anlauf et al., 1994; Boudries and Bottenheim, 2000]. The duration of the episodes at a ground site is controlled mostly by meteorology that drives changes in horizontal and vertical advection and mixing [Leaitch et al., 1994; Solberg et al., 1996; Hopper et al., 1998]. Experiments made at Alert, Ny-Ålesund $\left(79^{\circ} \mathrm{N}\right.$, $12^{\circ} \mathrm{E}$ ) and other Arctic locations have shown that ozone destruction occurs in the usually stable surface layer above the ocean snow/ice pack when solar insolation returns in spring and becomes sufficient for activation of reactive halogen constituents [Barrie and Platt, 1997; Barrie et al., 1998; Platt and Moortgat, 1999]. Novel analyses from these programs have demonstrated that both reactive chlorine and bromine constituents are involved but that destruction of ozone is dominated by catalytic cycles of $\mathrm{Br}$ atoms and $\mathrm{BrO}$ radicals [Bottenheim et al., 1990, 1993; Jobson et al., 1994; Hausmann and Platt, 1994; Muthuramu et al., 1994; Le Bras and Platt, 1995; Shepson et al., 1996; Impey et al., 1997, 1999; Ramacher et al., 1999; Rudolph et al., 1999] as was originally suggested by Barrie et al. [1988]. BrO mixing ratios as high as 1730 pptv have been directly measured at Alert and at Ny-Âlesund during ozone depletion events (ODEs) [Hausmann and Platt, 1994; Tuckermann et al., 1997; Perner et al., 1999]. Enhanced tropospheric $\mathrm{BrO}$ has also been measured over the Arctic region remotely by the European Research Satellite [Richter et al., 1998; Wagner and Platt, 1998] and from a high altitude aircraft [McElroy et al., 1999]. Loss of ozone attributed to reactive bromine has also been reported in the Antarctic [Kreher et al., 1997; Wessel et al., 1998] and over the Dead Sea [Hebestreit et al., 1999; Matveev et al., 2001]. Most recently, Foster et al. [2001] have reported mixing ratios of $\mathrm{Br}_{2}$ and $\mathrm{BrCl}$ at Alert as large as 25 and 35 pptv, respectively, in depletion events where $\mathrm{O}_{3}$ was reduced to $10-20$ ppbv. Both of these constituents are easily photolyzed and because $\mathrm{Cl}_{2}$ was not detected they concluded that $\mathrm{BrCl}$ was the dominant source of $\mathrm{Cl}$, a possibility suggested by Le Bras and Platt [1995].

[3] Although the source of reactive halogen constituents is currently favored to originate from sea salt deposited on the snow/ice pack rather than from airborne aerosols [Barrie and Platt, 1997], the precise mechanism that triggers reactive halogen release and maintains cycling in the atmosphere remains elusive. A number of suggestions have been made which when incorporated in models can reproduce ozone destruction quite well [Finlayson-Pitts et al., 1990; Fan and Jacob, 1992; McConnell et al., 1992; Le Bras and Platt, 1995; Mozurkewich, 1995; Tang and McConnell, 1996; Lehrer et al., 1997; Sander et al., 1997; Oum et al., 1998; Michalowski et al., 2000]. Depletion of $\mathrm{O}_{3}$ to mixing ratios less than a ppbv requires only $1-$ 2 days in these models. A current favorite for recycling is reaction (1), which occurs in the acidic medium of the snow/ ice pack.

$$
\mathrm{HOBr}+\mathrm{Br}_{(\mathrm{aq})}^{-}+\mathrm{H}_{(\mathrm{aq})}^{+} \rightarrow \mathrm{Br}_{2(\mathrm{aq})}+\mathrm{H}_{2} \mathrm{O}
$$

$\mathrm{HOBr}$ is formed from gas phase reaction of $\mathrm{BrO}$ with $\mathrm{HO}_{2}$ or by $\mathrm{BrONO}_{2}$ hydrolysis on airborne particles or the snow surface [Fan and Jacob, 1992; Tang and McConnell, 1996]. $\mathrm{Br}_{2(\mathrm{aq})}$ is released to the gas phase and can undergo subsequent photolysis to $\mathrm{Br}$ atoms. Since one $\mathrm{HOBr}$ can release up to two $\mathrm{Br}$ atoms in the presence of sufficient $\mathrm{Br}_{(\mathrm{aq})}^{-}$, a net growth in reactive bromine can occur, the socalled bromine explosion [Platt and Lehrer, 1996]. However, once $\mathrm{O}_{3}$ and hydrocarbons have been reduced to small mixing ratios in aged depletion events it is not clear what processes maintain formation of $\mathrm{HOBr}$.

[4] The snowpack at Alert has been shown to release photolyzable halogens even in the dark period [Impey et al., 1997, 1999; Foster et al., 2001]. The more recent discovery that the sunlit snow surface can be a chemically reactive medium that releases carbonyls [Sumner and Shepson, 1999; Couch et al., 2000], reactive nitrogen [Dibb et al., 1998; Munger et al., 1999; Honrath et al., 1999, 2000a, 2000b; Weller et al., 1999; Jones et al., 2000; Ridley et al., 2000; Davis et al., 2001], and other constituents [Ariya et al., 1999] to the surface layer has added complexity to understanding all of the chemical processes involved in ozone loss and production. $\mathrm{O}_{3}$ depletion often occurs throughout the vertical extent of the surface layer which is typically only 200-400 m deep [Anlauf et al., 1994; Leaitch et al., 1994; Jaeschke et al., 1999]. Because surface layer stability can effectively inhibit vertical mixing in the Arctic it is not clear how or whether the surface emissions affect the chemistry throughout the depth of the surface layer especially if the vertical mixing time constant is comparable to or longer than the photochemical lifetime of the emitted species.

[5] During the Tropospheric Ozone Production about the Spring Equinox (TOPSE) aircraft program the location, frequency, vertical structure, and some of the chemical and aerosol character of ODEs was investigated using the NASA Langley ozone/aerosol Differential Absorption Lidar (DIAL) which viewed nadir and zenith directions and the suite of in situ instruments on board the NCAR C130 aircraft. Here we discuss these observations and compare the chemical character of ODEs with those of nondepleted surface layers. We begin with a brief description of the experiment, an overall summary of when and where ODEs were observed, and follow with a more detailed qualitative discussion of examples of observations made within the surface layer.

\section{Experiment}

[6] An overview of TOPSE including details of the aircraft payload and flight tracks is presented by E. Atlas et al. 
(The TOPSE experiment: Introduction, submitted to Journal of Geophysical Research, 2002, hereinafter referred to as Atlas et al., submitted manuscript, 2002). TOPSE consisted of seven deployments (a total of 38 research flights, each $\sim 6 \mathrm{hr}$ duration) beginning on 4 February and ending on 23 May 2000. The flight track for the sixth deployment from Jefferson County Airport (JeffCo, near Boulder, CO) to near the north pole via Winnipeg and Churchill $\left(58.8^{\circ} \mathrm{N}\right.$, $\left.94.1^{\circ} \mathrm{W}\right)$, Manitoba, and Thule Air Base $\left(76.5^{\circ} \mathrm{N}, 68.7^{\circ} \mathrm{W}\right)$, Greenland and the return is shown as an example in Figure 1. Each deployment was about a week in duration and not all deployments attained as high a latitude as in this example. It was recognized that DIAL would not always be able to probe the surface layer due to middle and lower level clouds so the aircraft was routinely flown at $30 \mathrm{~m}$ altitude above fairly smooth, usually frozen, marine regions for periods of $15-30 \mathrm{~min}(100-200 \mathrm{~km})$ when at latitudes near or north of Churchill. Because Churchill was a secondary base of operations, half (16 of 32) of these low level flight legs were flown over various regions of Hudson Bay. Others were flown over Lancaster Sound, Foxe Basin, North Baffin Bay, and the Kane Basin/Smith Sound region, which is part of the channel separating Ellesmere Island from Greenland. Low level legs were also made over the Arctic Ocean near and north of Alert in conjunction with the Alert-2000 ground-based experiment [Zhou et al., 2001]. These regions are all identified in Figure 1. A variety of surface conditions were overflown at $30 \mathrm{~m}$ altitude including solid snow/icepack, leads, and polynyas or combinations thereof, but no coarse surface feature obviously correlated with the presence, absence, or intensity of an ODE.

\section{Locations of ODEs and Overall Character}

[7] A summary of the location, vertical depth, and approximate minimum extent of ODEs detected by DIAL or from the low level flight legs is given in Table 1. For the first time ODEs were observed over Hudson Bay in the subarctic. One was an extensive event at least $600 \mathrm{~km}$ long, which persisted for at least 4 days ( $7-11$ April). Both backtrajectory analysis and inferences from the GOME satellite observations of $\mathrm{BrO}$ [e.g., Richter et al., 1998] indicate that this event was transported from the Arctic Ocean. Another ODE was detected by DIAL over Hudson Bay east of Churchill on 28 April. Details of the Hudson Bay events will be presented elsewhere. The most extensive ODE observed, at least in one dimension, covered the $\sim 900 \mathrm{~km}$ distance from $84^{\circ} \mathrm{N}$ over the Arctic Ocean to as far south as North Baffin Bay during the 27 April flight.

[8] Here, the ODEs are arbitrarily classified according to the observed ozone mixing ratio as major ODEs (MODEs, $\mathrm{O}_{3}<4$ ppbv) and partially depleted ozone events (PODEs, $4 \leq \mathrm{O}_{3} \leq 20 \mathrm{ppbv}$ ). Figure $2 \mathrm{a}$ gives a summary of $\mathrm{O}_{3}$ mixing ratio variations within and between the eight surface layer flight legs where ODEs were investigated in situ. For contrast, Figure $2 \mathrm{~b}$ shows the range of $\mathrm{O}_{3}$ within the surface layer for the majority of low altitude flight legs in which no ODE (NODE) occurred. In these plates, near-vertical lines show the strong gradient in $\mathrm{O}_{3}$ often observed on descent into or ascent from the low altitude leg. The minimum $\mathrm{O}_{3}$ observed in any ODE was 30 pptv which was measured

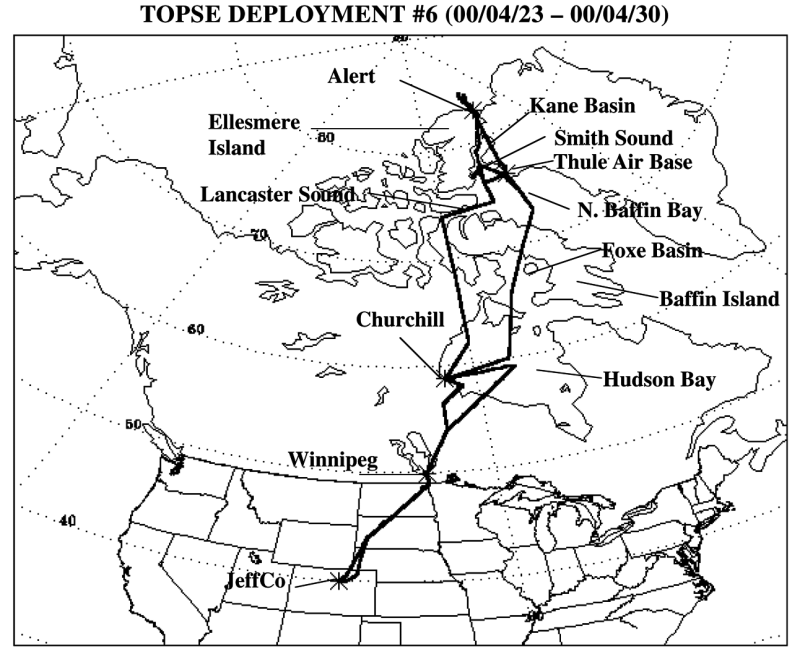

Figure 1. The flight track for deployment 6 from JeffCo to $84^{\circ} \mathrm{N}$ and return starting on 23 April and ending on 30 April. The figure also identifies regions that are discussed in the text. The Arctic Ocean lies north of all the landmasses shown in the figure.

during a low level flight leg over the Arctic Ocean near $84.6^{\circ} \mathrm{N}$ on 23 March (black trace in Figure $2 \mathrm{a}$ ). This case was the earliest example of an ODE found during TOPSE but PODEs were observed earlier from 2 to 6 March at the Alert ground site (K. Anlauf, private communication, 2001). The latest ODE observed during TOPSE was found near the end of the program when DIAL recorded an extensive depletion on a flight from Thule to Winnipeg on 22 May. Figure 3 shows this MODE which extended over the $\sim 600$ $\mathrm{km}$ distance from Thule west across North Baffin Bay to the east coast of Baffin Island.

[9] Table 2 summarizes the number of ODE encounters compared to the total number of low altitude flight legs for the various regions sampled. The table also includes observations of ODEs made by DIAL that could not be investigated in situ and a case labeled with a question mark where there was only a hint of ozone depletion. Even with clear skies, instrument limitations prevented DIAL from detecting ODEs over rough land terrain that is characteristic of much of the Arctic region overflown in TOPSE unless ozone depletion extended to an altitude greater than a few hundred meters. Also, DIAL could not detect ODEs from high altitude when low level clouds were present. Two exceptions were the 7 and 11 April flights where DIAL was able to detect ODEs that extended from Hudson Bay over the fairly smooth terrain of the western and northwestern Hudson Bay lowlands.

[10] From Table 2 the occurrence of ODEs at high latitudes but south of the Arctic Ocean region was rare. Of the 32 low level flight legs, 24 were classified as NODEs although Figure $2 b$ does reveal that three other cases may have had hints of ozone depletion or involved a mix of depleted and nondepleted air masses: Lancaster Sound (Flight 20, 21 March), Hudson Bay (Flight 32, 23 April) and Foxe Basin (Flight 35, 28 April) where minimum mixing ratios approached $24-27$ ppbv. The rarity of ODEs south of the Arctic Ocean is underscored by recognizing 
Table 1. ODEs During TOPSE

\begin{tabular}{|c|c|c|c|c|c|}
\hline Date & Flight & Route $^{\mathrm{a}}$ & Location & 〜Depth (m) & Type $^{\text {b }}$ \\
\hline $3 / 23$ & 21 & $\mathrm{~T}-\mathrm{T}$ & Arctic Ocean & 350 & MODE/PODE \\
\hline $4 / 04$ & 26 & C-T & West Lancaster Sound & 150 & PODE \\
\hline $4 / 06$ & 27 & $\mathrm{~T}-\mathrm{T}$ & Kane Basin & 500 & \\
\hline $4 / 07$ & 28 & $\mathrm{~T}-\mathrm{C}$ & DIAL: west and north Hudson Bay and over land (600 km) & 1000 & MODE \\
\hline $4 / 10$ & 29 & $\mathrm{C}-\mathrm{C}$ & Middle and west Hudson Bay DIAL mapping first ( $>300 \mathrm{~km})$ & $300-500$ & MODE \\
\hline $4 / 11$ & 30 & C-J & Hudson Bay near and east of Churchill, DIAL also overland & 600 & PODE \\
\hline \multirow[t]{2}{*}{$4 / 27$} & 34 & $\mathrm{~T}-\mathrm{T}$ & Arctic Ocean & 1100 & MODE \\
\hline & & & $\begin{array}{l}\text { Kane Basin/Smith Sound DIAL also and over } \\
\text { N. Baffin Bay }\end{array}$ & $500-250$ & PODE \\
\hline \multirow[t]{2}{*}{$4 / 28$} & 35 & $\mathrm{~T}-\mathrm{C}$ & DIAL: N. Foxe Basin and & 1500 & \\
\hline & & & Hudson Bay east of Churchill & 1000 & \\
\hline $5 / 19$ & 40 & $\mathrm{~T}-\mathrm{T}$ & Arctic Ocean & $150-230$ & PODE \\
\hline $5 / 22$ & 41 & T-W & $\begin{array}{l}\text { DIAL: from Thule across Baffin Bay to Baffin Island }(600 \mathrm{~km}) \\
\text { in situ on takeoff }\end{array}$ & 2400 & MODE \\
\hline
\end{tabular}

${ }^{\mathrm{a}} \mathrm{T}$, Thule Air Base; C, Churchill, W, Winnipeg; J, JeffCo.

${ }^{\mathrm{b}} \mathrm{MODE} \mathrm{O}_{3}<4$ ppbv, PODE $4 \leq \mathrm{O}_{3} \leq 20$ ppbv.

that the Hudson Bay cases of 4-7 April, and the ODEs of flight 34 (Table 1) were in fact due to one depletion event. In contrast, on all three low level flights over the Lincoln Sea/Arctic Ocean, ODEs were encountered. Indeed, we shall argue in section 4 that almost all of the ODEs observed during TOPSE developed over the Arctic Ocean and observation of ODEs elsewhere was due to transport from the Arctic Ocean source. The one exception may have been the PODE observed over Lancaster Sound on 4 April. The ODEs found over Hudson Bay were transported over long distances from the Arctic Ocean north of Alaska and Siberia (E. Atlas, private communication, 2001). Jaeschke et al. [1999] also found that ODEs observed in their aircraft program originated in outflow from the north, or from the Arctic Ocean. This same conclusion from all of the TOPSE flights was unexpected because lower northern latitude marine regions would also suffer sea salt deposition on the snow/ice surface and experience a long dark winter period that might be necessary for collection of constituents within the surface snow/ice. Since the Arctic front is normally south of Hudson Bay in winter and early spring [Barrie, 1986], it would also be surprising if lower northern latitudes did not experience sufficiently stable meteorology for the day or so timescale required for ODE formation. Certainly sufficiently stable conditions occurred to allow transport of ODEs over long distances from the Arctic Ocean to Hudson Bay or to Baffin Bay. Thus it seems that there is some as yet unidentified critical feature of the Arctic Ocean region or its coastal landmasses that is required for the generation and recycling of reactive halogens in the surface layer.

[11] To give a flavor of constituent behavior in the three categories of ODEs, a summary of the means and medians of selected constituents or ratios over the 32 low level flight legs is given in Figure 4. More detailed information from individual flights, including $\mathrm{OH}$ and peroxy radical measurements, will be given in section 4 . The figure should not be overinterpreted. The NODE category contains a large number of samples and covers 24 different flights. In contrast, the number of samples in the PODE and MODE categories is reasonable but the number of different cases is only 5 and 3 , respectively. In any category the standard deviation is often quite large. The summaries also include possible seasonal variations. For
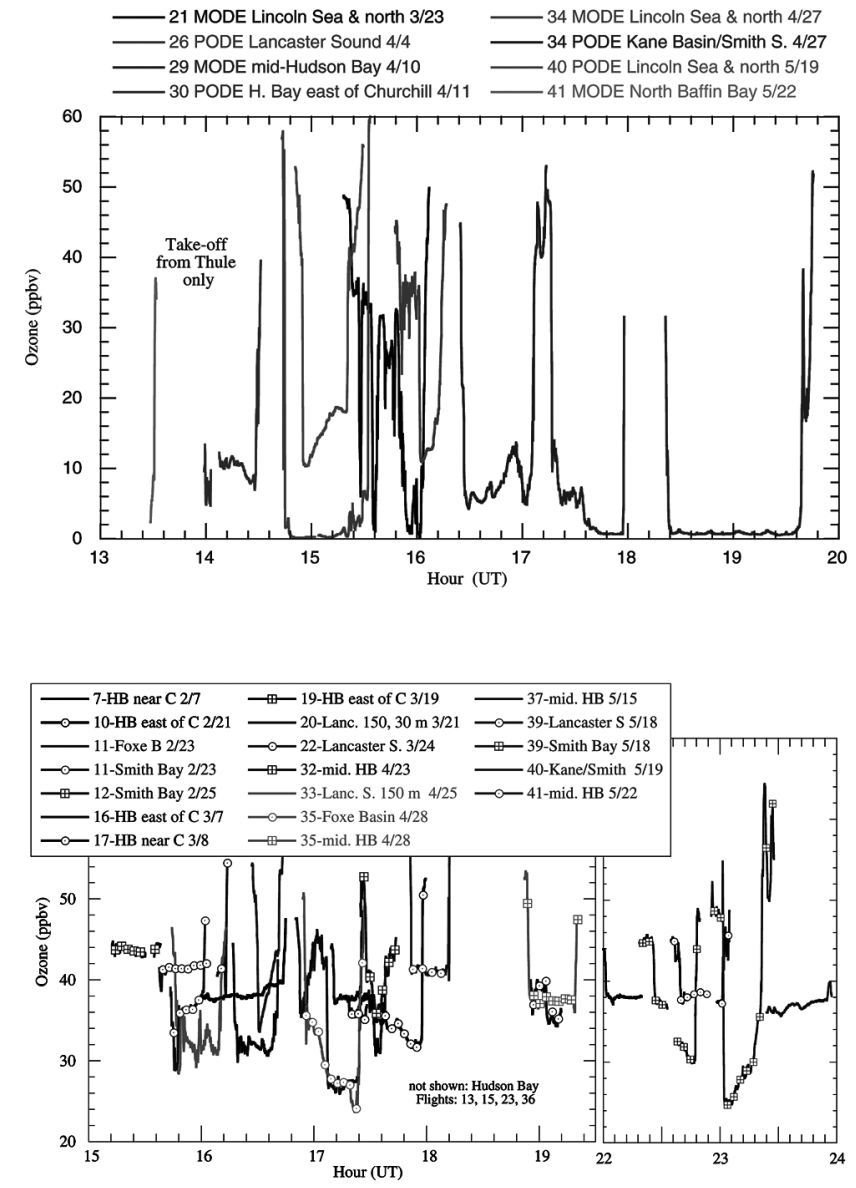

Figure 2. (a) Ozone mixing ratios for the ODEs encountered on low altitude flight legs within the surface layer. Most were at $30 \mathrm{~m}$ altitude but several were at $150 \mathrm{~m}$ altitude when visibility to lower altitudes was restricted. The vertical lines denote the gradient in ozone as the aircraft descended into or ascended from the low altitude flight leg. The locations are identified in Figure 1. (b) Ozone mixing ratios for most of the 24 low altitude flight legs where no clear ozone depletion was observed. The locations are identified in Figure 1. The legs are color coded from black to pink for increasing date. There is no obvious trend in ozone in these surface layer measurements from winter through spring. See color version of this figure at back of this issue. 
TOPSE
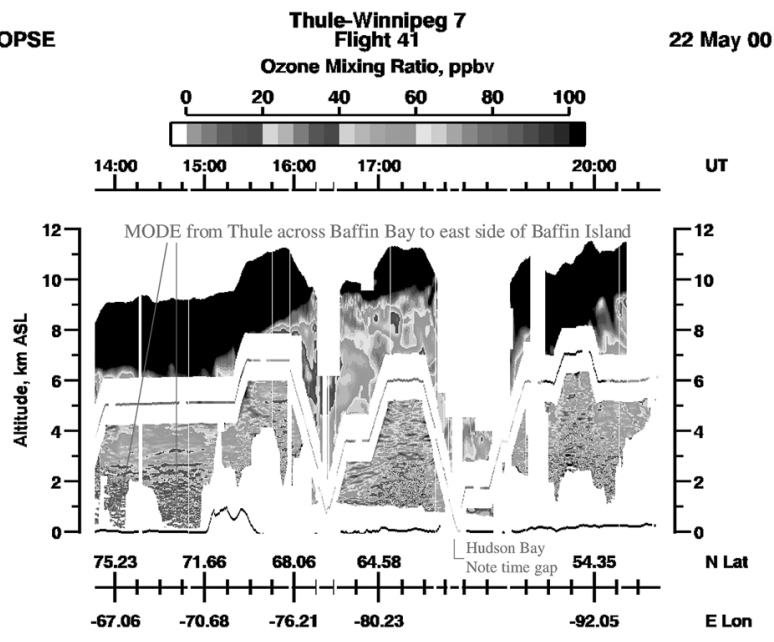

Figure 3. Zenith and nadir DIAL observations of ozone for Flight 41, 22 May from Thule Air Base to Winnipeg. Ozone was depleted from takeoff across Baffin Bay to the east side of Baffin Island, a distance of $600 \mathrm{~km}$, and to depths of $\sim 2.4$ $\mathrm{km}$. In the figure, the aircraft pressure altitude is denoted by the in situ ozone measurements, which are color coded as for the DIAL observations. Note that there is a gap in the DIAL data near 1730 UT when the aircraft descended for a low altitude leg over Hudson Bay. Higher ozone due to longrange transport from lower latitudes is also evident near 1700 UT between 2 and $6 \mathrm{~km}$ altitude. See color version of this figure at back of this issue.

example, a significant decline through winter to midspring was observed for some hydrocarbons and alkyl nitrates [Blake et al., 2002] but seasonal trends were small or insignificant for other constituents like $\mathrm{O}_{3}$, peroxyacetylnitrate $(\mathrm{PAN}), \mathrm{NO}_{\mathrm{y}}$ and $\mathrm{CO}$. (Seasonal trends in the latter constituents were observed at higher altitudes.) For example, in Figure $2 b$ the different legs are color coded (black to pink) by increasing date and there is no obvious trend in the surface layer ozone mixing ratios in the NODE cases. PAN also exhibited no significant seasonal variation in the surface layer while $\mathrm{NO}_{\mathrm{y}}$, and perhaps $\mathrm{HNO}_{3}$, showed a small decreasing trend with increasing season. Overall, any seasonal trend does not alter the qualitative trends depicted in Figure 4 for the surface layer. Last, except perhaps in the 23 March flight over the Arctic Ocean, we do not have information on the abundance of constituents in the air mass prior to major or partial ozone depletion so the trends, if any, are really measured between historically different air masses.

Table 2. ODE Encounters Versus Attempts from In Situ and DIAL Observations

\begin{tabular}{lcccc}
\hline \multicolumn{1}{c}{ Location } & ODEs & Attempts & Arguable & $\begin{array}{c}\text { Independent } \\
\text { DIAL Identification }\end{array}$ \\
\hline Hudson Bay & 2 & 16 & Flight 32 & 2 \\
Foxe Basin & 0 & 2 & Flight 35 & $1 ?$ \\
Lancaster Sound & 1 & 5 & Flight 20 & \\
North Baffin Bay & 1 & 4 & & 1 \\
Kane Basin & 1 & 2 & & 1 \\
Arctic Ocean & 3 & 3 & & \\
\hline
\end{tabular}

[12] The more robust trends are those for some hydrocarbons and soluble bromide (from any water soluble constituent such as $\mathrm{HBr}, \mathrm{HOBr}, \mathrm{BrONO}_{2}$, fine aerosol $\mathrm{Br}$ that would be sampled by the mist chamber technique) [Talbot et al., 1997]. As has been documented many times [Jobson et al., 1994; Ramacher et al., 1999; Ariya et al., 1999; Rudolph et al., 1999; Boudries and Bottenheim, 2000] alkanes (propane is given as an example) were significantly reduced in ODEs due to enhanced oxidation by chlorine atoms. Relatively larger destruction of ethyne (and trichloroethene, not shown) occurred which is also consistent with additional oxidation by $\mathrm{Br}$ atoms (B. C. Sive et al., Nonmethane hydrocarbon and halocarbon measurements made over the Arctic and high northern latitudes: Impact of halogen chemistry on Arctic lower tropospheric ozone, submitted to Journal of Geophysical Research, 2002, hereinafter referred to as Sive et al., submitted manuscript, 2002). The behavior of hydrocarbons, the increase in soluble bromide, and the increase in organic bromine constituents like $\mathrm{CH}_{3} \mathrm{Br}$ (not shown)
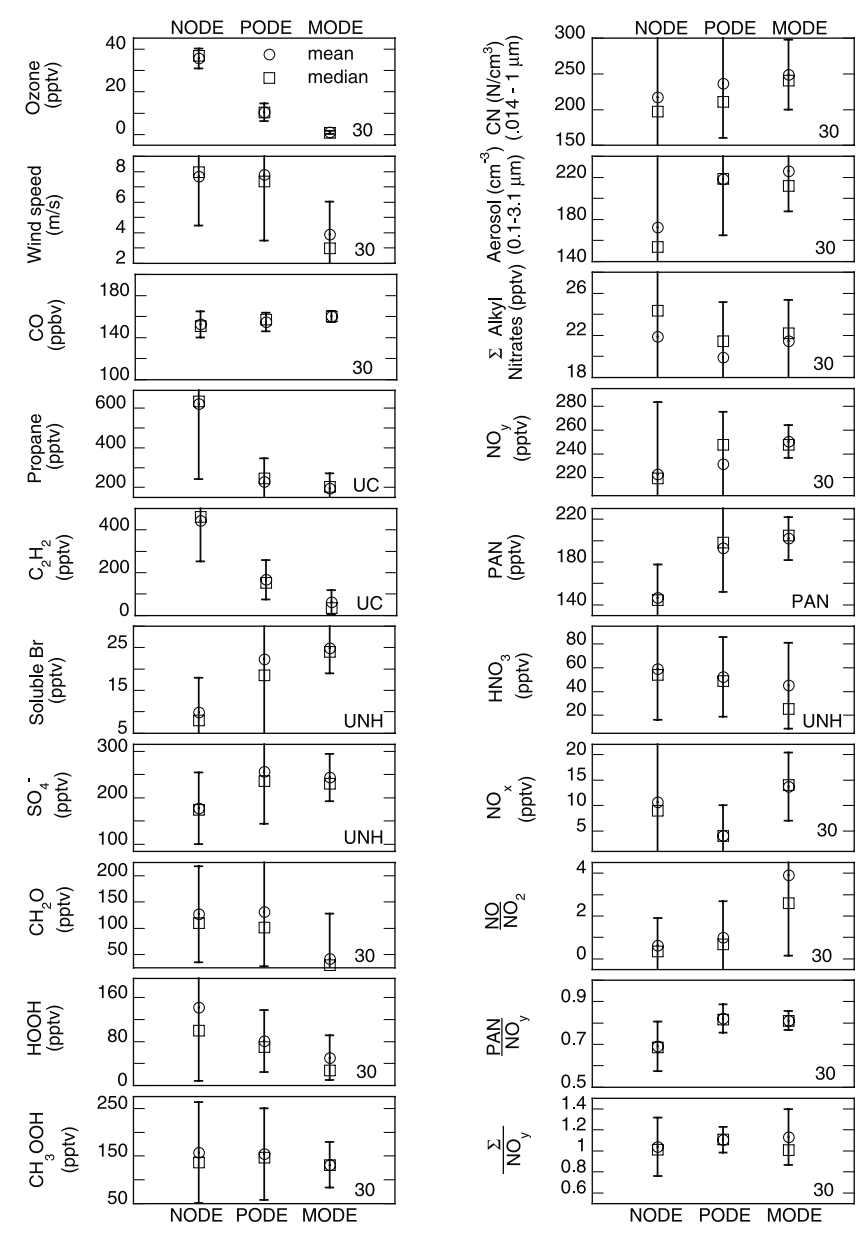

Figure 4. Average and medians of selected constituents for the three $\mathrm{O}_{3}$ categories. The time base for each plot is: 30, 30 s merged file; UC, canister sample collection interval; UNH, mist chamber collection interval; PAN, collection interval for the PAN sample. Soluble $\mathrm{Br}$ (bromide) is defined in the text. $\Sigma$ is the sum of PAN, $\mathrm{HNO}_{3}$, and $\mathrm{NO}_{\mathbf{x}}$. 
[Stroud et al., 1998] (O. W. Wingenter et al., Enhancements of $\mathrm{CH}_{3} \mathrm{Br}$ in the Arctic and sub-Arctic lower troposphere during spring 2000, unpublished data, 2001) are all qualitatively consistent with previous observations and analyses that have shown that atomic $\mathrm{Cl}$ and $\mathrm{Br}$ are responsible for ozone and hydrocarbon destruction in the surface layer either prior to or at the time of the aircraft observations.

[13] Other constituents that showed a decline from NODE to MODE conditions were $\mathrm{HOOH}$ and $\mathrm{HCHO}$. Although $\mathrm{HOOH}$ was quite variable in the nondepleted and partially depleted surface layer, median $\mathrm{HOOH}$ showed a decline from 100 pptv in NODE cases to 25 pptv, near the detection limit of the instrument, in MODE cases. In contrast, and although $\mathrm{CH}_{3} \mathrm{OOH}$ was in general more variable than $\mathrm{HOOH}$ in the low altitude legs irrespective of the $\mathrm{O}_{3}$ mixing ratio, there was little significant trend in the median mixing ratio. $\mathrm{HCHO}$ showed little change in the median from NODE to PODE conditions but a clear decline to a median of $25 \mathrm{pptv}$, also near the detection limit of the instrument, when ozone was reduced to less than 4 ppbv. Reasons for this behavior will be discussed in section 4.

[14] Reactive nitrogen constituents for NODE through MODE cases cover a range of behavior for the three categories of $\mathrm{O}_{3}$. In general all of these constituents were of small mixing ratio. Indeed the range of $\mathrm{NO}_{\mathrm{y}}$ or PAN over all of the low level legs was unexpectedly small and smallest in MODE cases. $\mathrm{NO}_{\mathrm{y}}$ and PAN medians in NODES were only 220 and 145 pptv, and in all categories of $\mathrm{O}_{3}$ they were rarely above 300 and $250 \mathrm{pptv}$. Using $\mathrm{NO}_{\mathrm{y}}$ as a measure of chemical "pollution" during the 32 surface layer flights only two cases were observed where moderately large mixing ratios were found and both cases were flights made east or southeast of Churchill. On the 7 February and 19 March flights $\mathrm{NO}_{\mathrm{y}}$ was as large as 410 and $550 \mathrm{pptv}$, respectively, for several minutes. The small standard deviation of the $\mathrm{CO}$ data and uniformity across the different $\mathrm{O}_{3}$ cases is also consistent with surprisingly few episodes of long-range transport of emissions from southern latitudes within the surface layer. The rarity of such events in the surface layer was surprising considering the ubiquity of Arctic haze [Barrie, 1986]. It is not clear how the relatively small range of $\mathrm{NO}_{\mathrm{y}}, \mathrm{PAN}$, or $\mathrm{CO}$ was maintained considering that the Arctic in winter and spring is subject to large changes in the sources of long-range transport from lower latitudes in winter and spring [Hopper et al., 1998; Worthy et al., 1994; Klonecki et al., 2002]. The results imply that most transport from continental surface sources occurs above the Arctic surface layer.

[15] Like CO, the sum of lighter alkyl nitrates (= methyl+ ethyl- $+i$-propyl- $+n$-propyl- +2 -butyl-nitrate) showed no significant trend with $\mathrm{O}_{3}$ and were consistent with observations made at Alert in 1988 [Bottenheim et al., 1993], in 1992 [Muthuramu et al., 1994], and in 1998 [Stroud et al., 1998]. During TOPSE this suite of alkyl nitrates constituted $\sim 10 \%$ of $\mathrm{NO}_{\mathrm{y}}$ in late March to $\sim 5 \%$ of $\mathrm{NO}_{y}$ in mid-May in the surface layer. $\mathrm{HNO}_{3}$ mixing ratios were typically small at $25-50 \mathrm{pptv}$ in the surface layer irrespective of the $\mathrm{O}_{3}$ content. From the medians, there is perhaps a suggestion of smallest mixing ratios in MODE conditions. Both PAN, $\mathrm{NO}_{\mathrm{y}}$, and the PAN/NO fraction increased as $\mathrm{O}_{3}$ was reduced which might suggest enhanced production of PAN when halogen chemistry is activated [Shepson et al., 1996]. Whether this is a robust result will be considered when specific examples are discussed in section 4.

[16] The $\mathrm{NO}_{\mathrm{x}}$ behavior was more complicated. There was a tendency for $\mathrm{NO}_{\mathrm{x}}$ to be a minimum in PODEs and to have larger values in MODEs. Possible reasons for this behavior are discussed relevant to individual flights in section 4. This trend, however, was not seen in the early season MODE of 23 March when solar insolation was quite low. It was observed in the MODE over the Arctic Ocean on 27 April and the Hudson Bay MODE of 7 April when solar elevation angles were much higher. In these higher insolation cases, a clear trend of increasing median $\mathrm{NO} / \mathrm{NO}_{2}$ ratios occurred in MODEs as shown in Figure 4 as would be expected qualitatively for the much reduced $\mathrm{O}_{3}$.

[17] Figure 4 also shows that median $\mathrm{NO}_{\mathrm{x}}$ in any category was near or below $15 \mathrm{pptv}$ at $30 \mathrm{~m}$ altitude. Mixing ratios up to a factor of 2 or more higher have been measured within a few meters of the surface at Alert [Ridley et al., 2000; Beine et al., 2002] and at Ny-Ålesund [Beine et al., 1997]. Much larger mixing ratios of NO alone (150-500 pptv) have been reported in late spring in the Antarctic surface layer [Davis et al., 2001]. Clearly, for the Arctic region, the impact of surface emissions of $\mathrm{NO}_{\mathrm{x}}$ or its precursors is not large at $30 \mathrm{~m}$ altitude. However, as will be shown in section 4, the Arctic surface layer is often very stable so that vertical mixing from the surface can be very inefficient.

[18] There is no significant trend in the ratio of the sum of principal constituents to measured $\mathrm{NO}_{\mathrm{y}}$ for the three categories of $\mathrm{O}_{3}$ in the surface layer. The ratio is restricted here to PAN $+\mathrm{HNO}_{3}+\mathrm{NO}_{\mathrm{x}}$ in Figure 4 only to increase the number of measurements for each category. When alkyl nitrates and peroxypropionyl nitrate (PPN) are included, measured $\mathrm{NO}_{\mathrm{y}}$ was on average lower than the sum of individual constituents by $10-15 \%$ which is just within estimated errors in the measurements and their relative contributions to the fraction. Last, the surface layer data for an individual flight are not sufficiently accurate to infer meaningful mixing ratios of other possible nitrogen species such as $\mathrm{HONO}, \mathrm{HO}_{2} \mathrm{NO}_{2}, \mathrm{~N}_{2} \mathrm{O}_{5}$, or halogen nitrates.

[19] When comparing the aerosol behavior for the three categories of $\mathrm{O}_{3}$ there is no clear-cut distinction in the $\mathrm{CN}$ data and perhaps a suggestion of elevated $0.1-3.3 \mu \mathrm{m}$ particles in MODEs. However, the range observed for the larger size range in the case of no ozone depletion was large [e.g., Browell et al., 2002]. For the size range of particles measured on these flights, there was no obvious correlation with the presence or absence of $\mathrm{O}_{3}$ depletion.

\section{Specifics of Individual ODEs}

\subsection{Arctic Ocean ODE of 23 March (Flight 21)}

[20] This flight was the earliest opportunity to probe the surface layer in the high Arctic. A $30 \mathrm{~m}$ altitude leg was started over the Arctic Ocean/Lincoln Sea about $20 \mathrm{~km}$ east of Alert and continued nearly due north for $\sim 220 \mathrm{~km}$ to $84.6^{\circ} \mathrm{N}$. At these locations the sky in the region was clear 
and the surface bright but insolation was low since the solar elevation angle was only $7^{\circ}-8^{\circ}$. No open leads were observed in the snow/ice surface during this leg and no ODE was observed at the ground site near Alert on this day (K. Anlauf, private communication, 2001).

[21] $\mathrm{O}_{3}$ and some other measurements made at $1 \mathrm{~s}$ time resolution $(\sim 100 \mathrm{~m}$ horizontal resolution) are shown in Figure 5. Depleted $\mathrm{O}_{3}$ was not observed until several minutes after the aircraft had descended to $30 \mathrm{~m}$ altitude. Thereafter it was remarkably structured on short and longer timescales with mixing ratios alternating essentially between the extremes of MODE and NODE conditions. Although relative humidity was higher and wind speed low in the surface layer there was no obvious connection between any of the other measurements shown in Figure 5 and the variations in $\mathrm{O}_{3}$. At $30 \mathrm{~m}$ altitude the lowest $\mathrm{O}_{3}$ was $250 \mathrm{pptv}$. The smallest mixing ratio of only $30 \mathrm{pptv}$ was recorded near $150 \mathrm{~m}$ altitude during the ascent farthest north (near 57,695 s in Figure 5). We do not know whether this minimum $\mathrm{O}_{3}$ occurred well above the surface in general in the MODE that started near 57,000 s or whether more complete depletion intensified at all altitudes in the surface layer farther north. The latter possibility seems unlikely because $\mathrm{O}_{3}$ started to increase to $6-8 \mathrm{ppbv}$ just before the start of the ascent, that is, the northern edge of the event might have been encountered at $30 \mathrm{~m}$ but not at higher altitude. We also cannot determine whether the variability observed in $\mathrm{O}_{3}$ at $30 \mathrm{~m}$ was the result of encountering a number of spatially separated small areas of depleted $\mathrm{O}_{3}$ or whether the aircraft just happened to fly along the ragged edge of a large region of depletion. Although the flight track after ascent was designed to explore the region from higher altitude with the DIAL instrument, the nadir channel suffered a problem so no further information on the areal extent of the ODEs is available.

[22] Back-trajectories offer some insight on the $\mathrm{O}_{3}$ variability. Examples ending on the flight track for the time of Figure 5 are shown in Figure 6; they indicate air mass origins of trajectories from the south with flow up the channel separating Greenland and Ellesmere Island. It is possible that halogen activation and $\mathrm{O}_{3}$ depletion occurred farther south in the Arctic but clouds over the channel at lower latitudes prevented DIAL from seeing the surface layer. However, we suggest that the depletion occurred over the Arctic Ocean and that the flow from the south contributed to the inhomogeneity of the ODEs observed at 30 $\mathrm{m}$. That is, the flight region was undergoing displacement and mixing of depleted air over the Arctic Ocean with undepleted air from the south. Trajectories examined for the flight region over an extended period switched to being mostly from residence over the Arctic Ocean to flow from the south about 18 and 19 March and then north from the Arctic Ocean again on 3 and 4 April. That the Alert ground site observed variable intensity ODEs from 5 to 17 March and a MODE on 5 April has some consistency with the trajectory changes.

[23] Vertical structure measured with faster response instruments $(5-10 \mathrm{~m}$ vertical resolution) on descent into the undepleted surface layer and on ascent from the depleted air mass $\sim 220 \mathrm{~km}$ farther north are shown in Figure 7 . In both cases, the surface layer was not capped by an inversion aloft but sustained a substantial surface inversion and there- fore very stable air below $\sim 500 \mathrm{~m}$. Above $500 \mathrm{~m}$ and up to $3500 \mathrm{~m}$ the lower troposphere was nearly isothermal (not shown). A decline of $\mathrm{O}_{3}$ from 48 to $35 \mathrm{ppbv}$ occurred as the aircraft descended through 250 to $30 \mathrm{~m}$ but we consider that the descent was initially into undepleted air or into air with a modest admixture of depleted air. On ascent from strongly depleted air, $\mathrm{O}_{3}$ remained less than 20 ppbv up to only 320 $\mathrm{m}$ altitude and was less than $30 \mathrm{ppbv}$ up to $450 \mathrm{~m}$. Winds were light but comparable in both the descent and ascent region.

[24] During ascent $\mathrm{NO}_{\mathrm{y}}$ was reduced in the depleted air compared to higher altitudes but below $450 \mathrm{~m}$ the mixing ratios were comparable to those observed in the undepleted air of the descent. (The instrument was in an internal system check for the first part of the descent so ambient data is missing.) Changes in $\mathrm{CN}$ between ascent and descent are more interesting. $\mathrm{CN}$ was not strongly correlated with $\mathrm{NO}_{\mathrm{y}}$ in either the descent or ascent when below $\sim 500 \mathrm{~m}$ but they were positively correlated above $500 \mathrm{~m}$. On descent a stepped decline in $\mathrm{CN}$ from 330 to $280 \mathrm{~cm}^{-3}$ started at $400 \mathrm{~m}$ followed by a further reduction to a near-constant $230 \mathrm{~cm}^{-3}$ below $175 \mathrm{~m}$. On ascent from depleted air multiple narrow layers of $\mathrm{CN}$ were found up to $500 \mathrm{~m}$ but the peaks in concentration were not particularly large for Arctic haze layers [Barrie, 1986]. These thin layers were colocated with increases in the depleted $\mathrm{O}_{3}$ mixing ratio suggesting, from the profile data, that $\mathrm{O}_{3}$ and $\mathrm{CN}$ were perhaps positively associated. In contrast, the top panel of Figure $8 \mathrm{a}$ shows that a substantial increase in $\mathrm{CN}$ was observed each time an ODE was encountered while at 30 $\mathrm{m}$ altitude. This behavior was not observed by the larger particle instrument probes $(0.3-20 \mu \mathrm{m}$ probe, $0.12-3.12$ $\mu \mathrm{m}$ probe) and it contradicts earlier observations made by Staebler et al. [1994] and Leaitch et al. [1994]. In their ground-based and aircraft-based measurements made near or north of Alert, nucleation mode particles were positively associated with $\mathrm{O}_{3}$, the opposite of that shown in Figure 8a. Thus, and although it would be more interesting to suggest that our observations demonstrate production of fine aerosols by the chemistry occurring in ODEs, it is more likely that the anticorrelation resulted from transport processes. If the variations in $\mathrm{O}_{3}$ were actually due to convergence of depleted air over the Arctic Ocean and undepleted air from the south then the anticorrelation could have been due to differences in the original (higher) content of $\mathrm{CN}$ in the air mass that underwent $\mathrm{O}_{3}$ destruction compared to a lower content in the air mass from the south. Even this explanation does not bear scrutiny because the anticorrelation of $\mathrm{O}_{3}$ and $\mathrm{CN}$ was robust at constant altitude until $57,540 \mathrm{~s}$ or when the aircraft started to ascend from the ODE. Between 70 and $150 \mathrm{~m}$ altitude, the same altitude region where $\mathrm{O}_{3}$ reached its minimum mixing ratio (cf. Figure 7), CN was not enhanced. We have no explanation for this intriguing difference although we shall see that HCHO and soluble bromide data (but not hydrocarbon data) also reveal a discontinuity at the same time. It is possible that the age of (or halogen activation within) the depleted air near $30 \mathrm{~m}$ was different from that at $70-150 \mathrm{~m}$, that is, that two or more historically different ODE layers were encountered on ascent.

[25] Normal photochemical activity as measured by the concentration of $\mathrm{HO}_{\mathrm{x}}=\mathrm{OH}+\mathrm{RO}_{2}$, where $\mathrm{RO}_{2}$ includes 


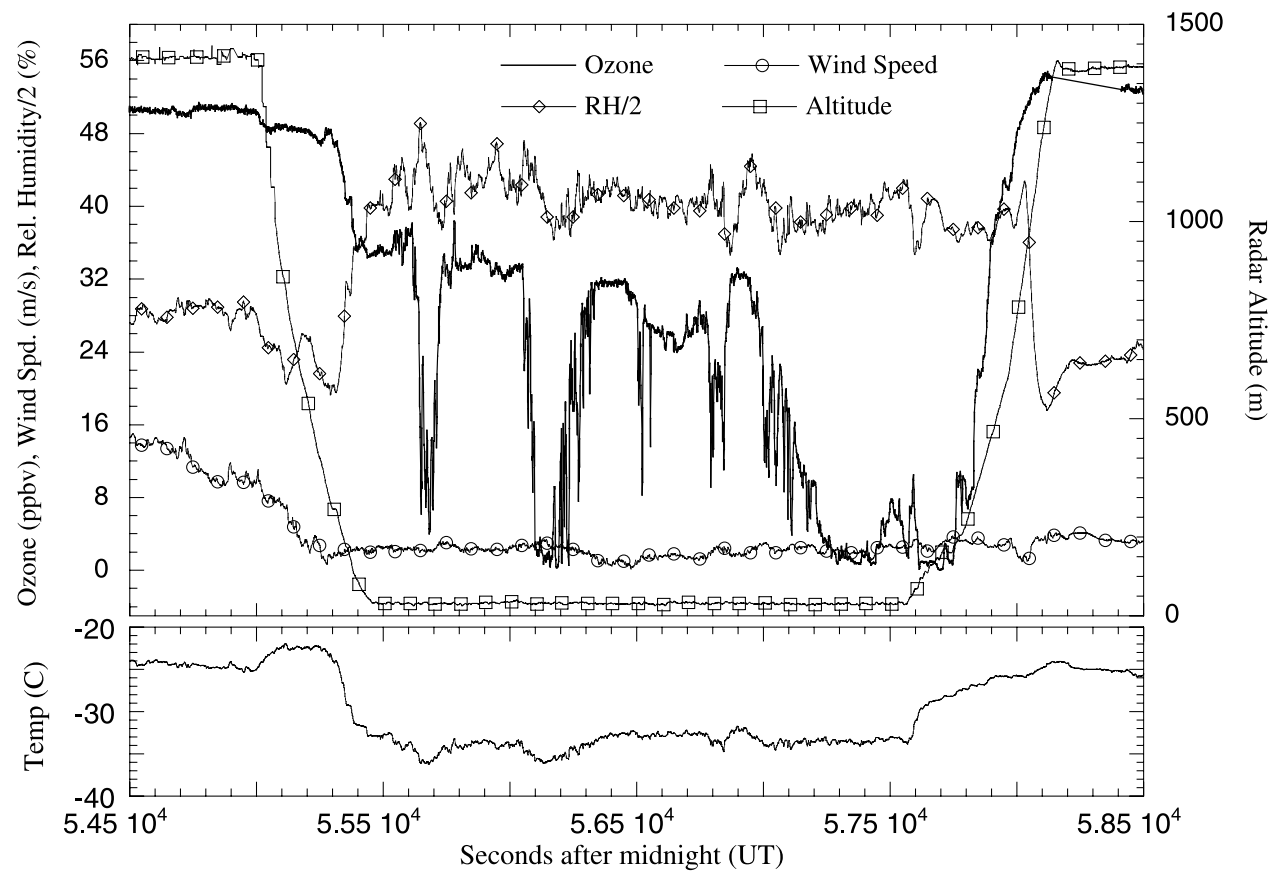

Figure 5. $\mathrm{O}_{3}$, temperature, wind speed, relative humidity, and radar altitude for the low altitude flight leg over the Arctic Ocean/Lincoln Sea region on 23 March (Flight 21). All data are at $1 \mathrm{~s}$ time resolution equivalent to $\sim 100 \mathrm{~m}$ horizontal resolution.

$\mathrm{HO}_{2}$ plus $\mathrm{CH}_{3} \mathrm{O}_{2}$ and higher carbon number peroxy radicals, was low within the surface layer as is illustrated in Figure 8a. Measurement of $\mathrm{HO}_{\mathrm{x}}$ constituents in dry Arctic air at a solar elevation of only $7^{\circ}-8^{\circ}$ is a severe test of instrument capability and it is clear from the figure that the $\mathrm{OH}$ instrument was operating near its detection limit $(\leq 1 \times$ $10^{5} \mathrm{~cm}^{-3}$ for a $10 \mathrm{~min}$ average). It was not able to distinguish any difference between ODE and NODE conditions or changes with altitude. Median $\mathrm{OH}$ for the $30 \mathrm{~m}$ leg was only $0.4 \times 10^{5} \mathrm{~cm}^{-3}$. The measurements are in coarse agreement with the results from a calculation that solves simultaneously the steady state equations for the chemical constituents initiated by their observed concentrations [Cantrell et al., 2002]. Production of $\mathrm{HO}_{x}$ from $\mathrm{O}_{3}$ and water was clearly limited by the low insolation $\left(\mathrm{J}\left(\mathrm{O}_{3}\right)<\right.$ $\left.7 \times 10^{-7} \mathrm{~s}^{-1}\right)$, low absolute water mixing ratio $(<0.2 \mathrm{gm} /$ $\mathrm{kg}$ ), and in the ODE regions, small $\mathrm{O}_{3}$. Modulation of $\mathrm{OH}$ might have been expected due to the large changes in $\mathrm{O}_{3}$ compounded by the simultaneous positive correlation between $\mathrm{O}_{3}$ and $\mathrm{HCHO}$ that occurred while at $30 \mathrm{~m}$ altitude prior to $57,500 \mathrm{~s}$ which is shown in the bottom panel of Figure 8a. Thus in the ODEs both photolytic sources of $\mathrm{OH}$ would be strongly reduced. The steady state calculation does resolve these changes but they are quite small with an amplitude of $\sim 0.5 \times 10^{5} \mathrm{~cm}^{-3}$ and clearly beyond the precision of the $\mathrm{OH}$ instrument on this flight.

[26] The $\mathrm{RO}_{2}$ measurements were also small with a median for the $30 \mathrm{~m} \mathrm{leg}$ of $4.6 \times 10^{7} \mathrm{~cm}^{-3}$ and were also invariant with altitude or with changes in $\mathrm{O}_{3}$ or $\mathrm{HCHO}$. Expected trends of $\mathrm{RO}_{2}$ with $\mathrm{O}_{3}, \mathrm{HCHO}$, and other hydrocarbons are clearly seen in the steady state calculation. However, the steady state model does not include possible reactive halogen chemistry, which through reactions with
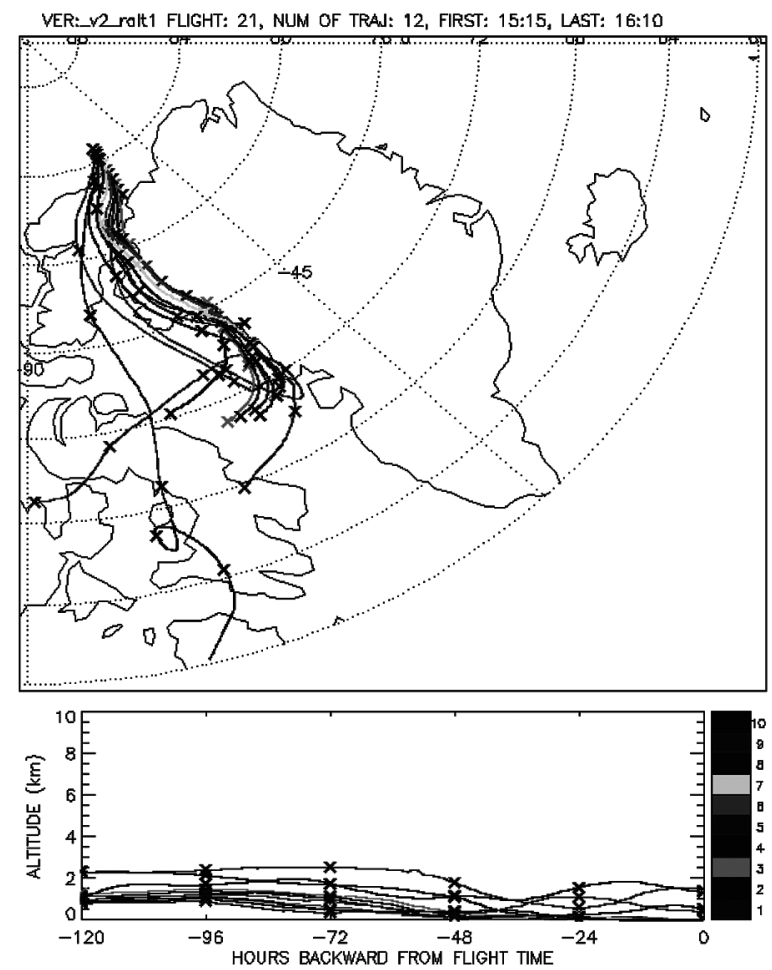

Figure 6. 5 day back-trajectories to the $30 \mathrm{~m}$ altitude leg and for final altitudes up to $1500 \mathrm{~m}$ for the 23 March flight corresponding to data shown in Figure 5. See color version of this figure at back of this issue. 

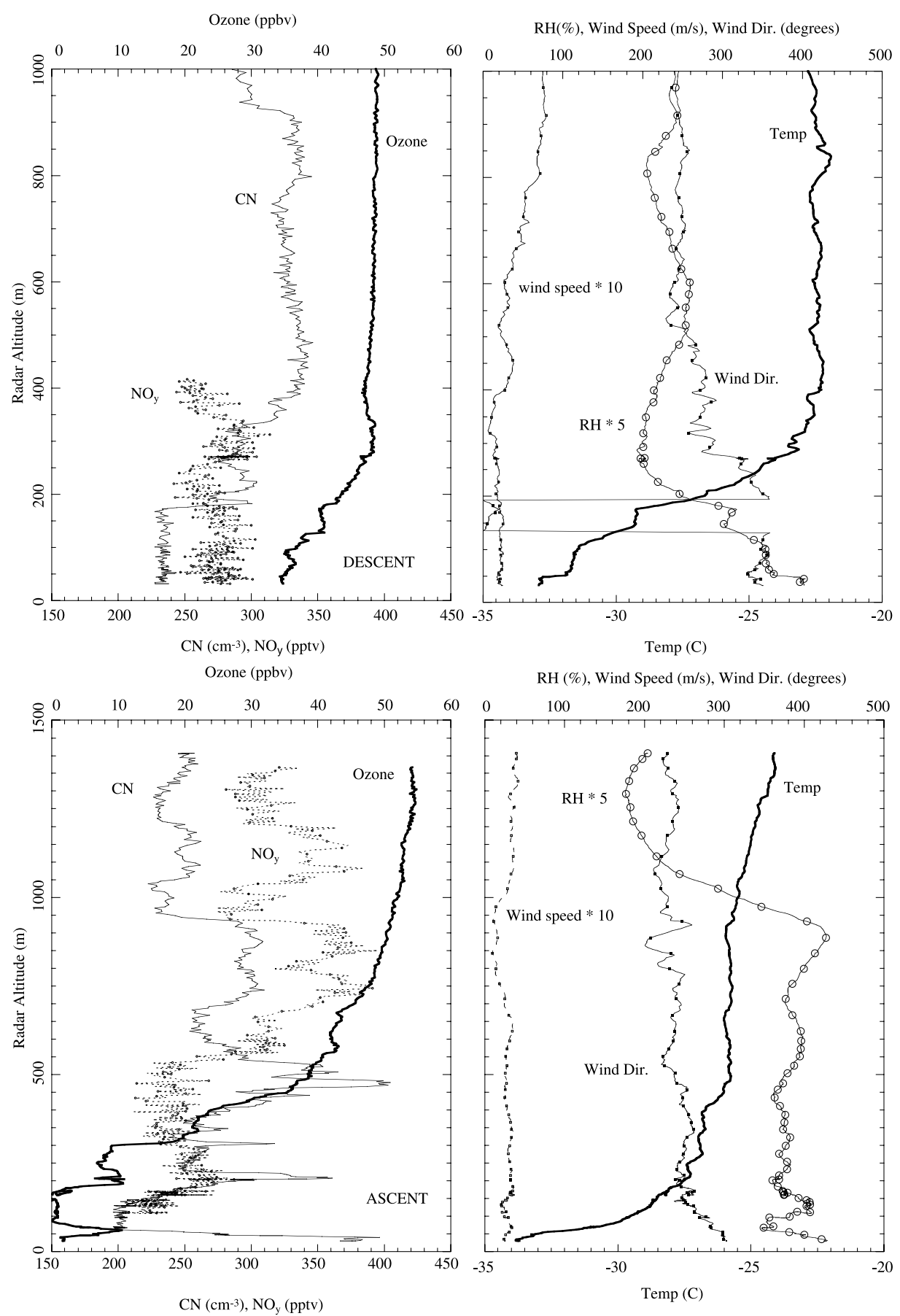

Figure 7. Profile data over the Arctic Ocean for Flight 21, 23 March showing the strong surface inversion. All of the data are $1 \mathrm{~s}$ corresponding to a vertical resolution of $5-10 \mathrm{~m}$. The descent to $30 \mathrm{~m}$ altitude was into essentially undepleted air in the surface layer. The ascent was from depleted air in the surface layer.

hydrocarbons including formaldehyde could constitute another source of peroxy radicals. With the very low NO observed during the low altitude leg the increase in $\mathrm{OH}$ production should be small. The median $\mathrm{RO}_{2}$ from the model without reactive halogens is a factor of 2 larger than measured during the $30 \mathrm{~m}$ altitude leg suggesting that halogen activity was low at the time of the flight and that major ozone destruction had occurred previously. Within the measurement precision and uncertainty at these low concen- trations there is no evidence of abnormal $\mathrm{HO}_{\mathrm{x}}$ concentrations in the ODEs compared to undepleted air masses.

[27] A clear demonstration of most likely previous halogen activity is also given in Figure 8a which includes the time series of soluble bromide, $\mathrm{CO}$, and two representative hydrocarbons, propane which is reactive with $\mathrm{OH}$ and $\mathrm{Cl}$, and ethyne which is additionally reactive with $\mathrm{Br}$. Soluble bromide was near the detection limit when at altitudes well above the surface layer $(1400 \mathrm{~m})$ and was clearly anticorre- 
lated with $\mathrm{O}_{3}$. Largest soluble bromide $(\sim 50 \mathrm{pptv})$ was observed in the northernmost ODE while at $30 \mathrm{~m}$. Like $\mathrm{CN}$, soluble bromide was not the largest in the layer of minimum $\mathrm{O}_{3}$ that occurred from 70 to $150 \mathrm{~m}$ altitude. It appears that chemical processing or the time for processing was different between the layer of minimum $\mathrm{O}_{3}$ and that at lower altitudes. $\mathrm{CO}$ was quite uniform with altitude between 30 and $1400 \mathrm{~m}$ and there was little gradient as the aircraft continued north. In contrast, the two hydrocarbons show a decline as the aircraft flew north at $30 \mathrm{~m}$ and their strong decrease to 0.2 and 0.6 of undepleted values for ethyne and propane in the ODE farthest north is qualitatively as expected for bromine and chlorine activation [e.g., Jobson et al., 1994]. For example, at the small mixing ratio of $\mathrm{OH}$ shown in Figure 8a, the lifetime of propane with respect to $\mathrm{OH}$ would be more than 6 months so clearly the reduction of propane observed in the ODEs requires previous or current halogen chemistry. However, we do not know the age of the depleted air, the concentration of reactive halogens, or indeed even whether halogen chemistry was still active in the ODEs at the time of the observations. Further analysis of the hydrocarbon variations is given by Sive et al. (submitted manuscript, 2002).

[28] HCHO mixing ratios are shown in the bottom panel of Figure 8a. Except for the large mixing ratio observed near $55,000 \mathrm{~s}, \mathrm{HCHO}$ was less than 25 pptv during legs made at $1400 \mathrm{~m}$ altitude before and after the descent to $30 \mathrm{~m}$ (where the altitude is off scale in Figure 8a). In mostly undepleted air while at $30 \mathrm{~m}$ altitude, $\mathrm{HCHO}$ increased substantially to 300-400 pptv. Production by $\mathrm{OH}$ reaction with hydrocarbons, or by reaction of hydrocarbons with $\mathrm{Cl}$ at typical concentrations of $8 \times 10^{4} \mathrm{~cm}^{-3}$ [Boudries and Bottenheim, 2000] is too small to maintain such large mixing ratios. Since the photolysis time constant for a near-noon solar elevation angle of $8^{\circ}$ is of order 1 or 2-3 days when averaged over the diurnal cycle, the large mixing ratios require a surface source as first reported by Sumner and Shepson [1999] at Alert. Indeed, the mixing ratios from the flight are comparable to those reported for Alert in undepleted air masses. Within the ODEs while at $30 \mathrm{~m}$ altitude, $\mathrm{HCHO}$ was reduced substantially to $50 \mathrm{pptv}$ or less although in the first event encountered near 55,700 s the $\mathrm{HCHO}$ reduction was observed over a considerably broader region than that for $\mathrm{O}_{3}$. The reduction in $\mathrm{HCHO}$ in depleted air is also consistent with an enhanced loss rate through reaction with atomic $\mathrm{Br}$ and $\mathrm{Cl}$ [Sumner and Shepson, 1999]. Although the vertical resolution is low, the descent shows that HCHO first increased to 300-400 pptv beginning at $\sim 200 \mathrm{~m}$ and that it remained fairly uniform in the same mixing ratio range in undepleted air while at $30 \mathrm{~m}$. Given the very stable conditions to about $500 \mathrm{~m}$, the lack of wind shear at least at the time of the aircraft flight, and the absence of heat sources from open leads in the region, the surface layer responsible for the ODE formation must have been intact for a very long time in order to have the surface source of HCHO mixed to as high as $200 \mathrm{~m}$. It is possible that some mixing was induced by the flow from the south impacting the Arctic Ocean air masses, but this mixing could not have been in existence for very long since other constituents like $\mathrm{O}_{3}$ and $\mathrm{CN}$ were not uniform within the surface layer. Again, like $\mathrm{CN}$ and soluble bromide behavior, the intriguing layer of minimum $\mathrm{O}_{3}$ encountered during ascent did not contain the expected small mixing ratio but rather a large (380 pptv) mixing ratio of $\mathrm{HCHO}$.

[29] Within the surface layer, irrespective of the $\mathrm{O}_{3}$ mixing ratio, $\mathrm{HOOH}$ was near or below the detection limit (25 pptv) of the instrument as shown in Figure 8b. Production would be limited by the low mixing ratios of $\mathrm{HO}_{2}$ and peroxide could also suffer surface deposition. At the small observed mixing ratio, hydrogen peroxide would also be a minor source of $\mathrm{OH}$. The mixing ratios are generally smaller than reported by de Serves [1994] under sunlit conditions at Alert in 1992. In contrast, $\mathrm{CH}_{3} \mathrm{OOH}$ during the low altitude flight leg was variable at $0-150$ pptv but there was no clear correspondence with the changes in $\mathrm{O}_{3}$.

[30] Reactive nitrogen constituent behavior is also shown in Figure $8 \mathrm{~b}$. It is clear that total reactive nitrogen was decoupled from the variations in $\mathrm{O}_{3}$ unlike the more usual positive association observed in spring and summer at midlatitudes. $\mathrm{HNO}_{3}$ was mostly near $20 \mathrm{pptv}$, showed no significant gradient with altitude to $1400 \mathrm{~m}$ altitude, and showed no consistent change linked to $\mathrm{O}_{3}$. Production of the acid would be limited by the small mixing ratios of $\mathrm{OH}$ and $\mathrm{NO}_{2}$. The other constituents, and thus $\mathrm{NO}_{\mathrm{y}}$, showed a small decline with decreasing altitude during the descent into or ascent from the surface layer. While at $30 \mathrm{~m}$ altitude mixing ratios were quite uniform with no consistent change as the aircraft transited between ODE and NODE air masses in contrast to the overall trends discussed in section 3 and shown in Figure 4. If the ODE and NODE cases are separate air masses from the Arctic Ocean and from more southern latitudes then it is surprising that PAN, alkyl nitrates, $\mathrm{NO}_{\mathrm{y}}$, and other constituents were so similar in mixing ratio. If this interpretation of air mass origin is wrong and the NODE and PODE masses were originally the same, then there was no consistent increase in PAN in the ODEs in contrast to the possibility of increased production of PAN suggested earlier [Shepson et al., 1996]. However, the availability of $\mathrm{NO}_{\mathrm{x}}$ would limit the formation of PAN on this flight. During the $30 \mathrm{~m} \mathrm{leg}$, and also at higher altitudes, PAN was by far the major $\mathrm{NO}_{\mathrm{y}}$ constituent and the major total peroxy nitrate in the surface layer in agreement with previous studies in spring at Alert and elsewhere [Bottenheim et al., 1993; Jaeschke et al., 1999; Ridley et al., 2000].

[31] In contrast to the HCHO data which implied the need of a surface source, there was no evidence of a significant surface source of $\mathrm{NO}_{\mathrm{x}}$ on this early spring flight in the surface layer. The $\mathrm{NO}$ and $\mathrm{NO}_{2}$ measurements were near the instrument detection limit ( 2 and 5 pptv, respectively, for a $30 \mathrm{~s}$ average) and there is an obvious overcorrection for the measurement artifact in the $\mathrm{NO}_{2}$ data since negative values were obtained. However, the precision indicates that a decline in the $\mathrm{NO}_{\mathrm{x}}$ mixing ratio occurred within the surface layer compared to higher altitudes. At Alert in 1998, when the noon solar zenith angle was similar to that of this flight $\left(82^{\circ}\right), \mathrm{NO}_{\mathrm{x}}$ at $5 \mathrm{~m}$ elevation from the snow surface was at most 5 pptv. Assuming that the source of $\mathrm{NO}_{\mathrm{x}}$ from the snow surface at Alert was similar to that over the Arctic Ocean, and that snow ventilation was similar, then the absence of an observed increase in the aircraft data at $30 \mathrm{~m}$ for these low Sun conditions is not too surprising considering the larger measurement uncertainty of the aircraft measurements. As well, at this time of year, formation of $\mathrm{N}_{2} \mathrm{O}_{5}$ at 

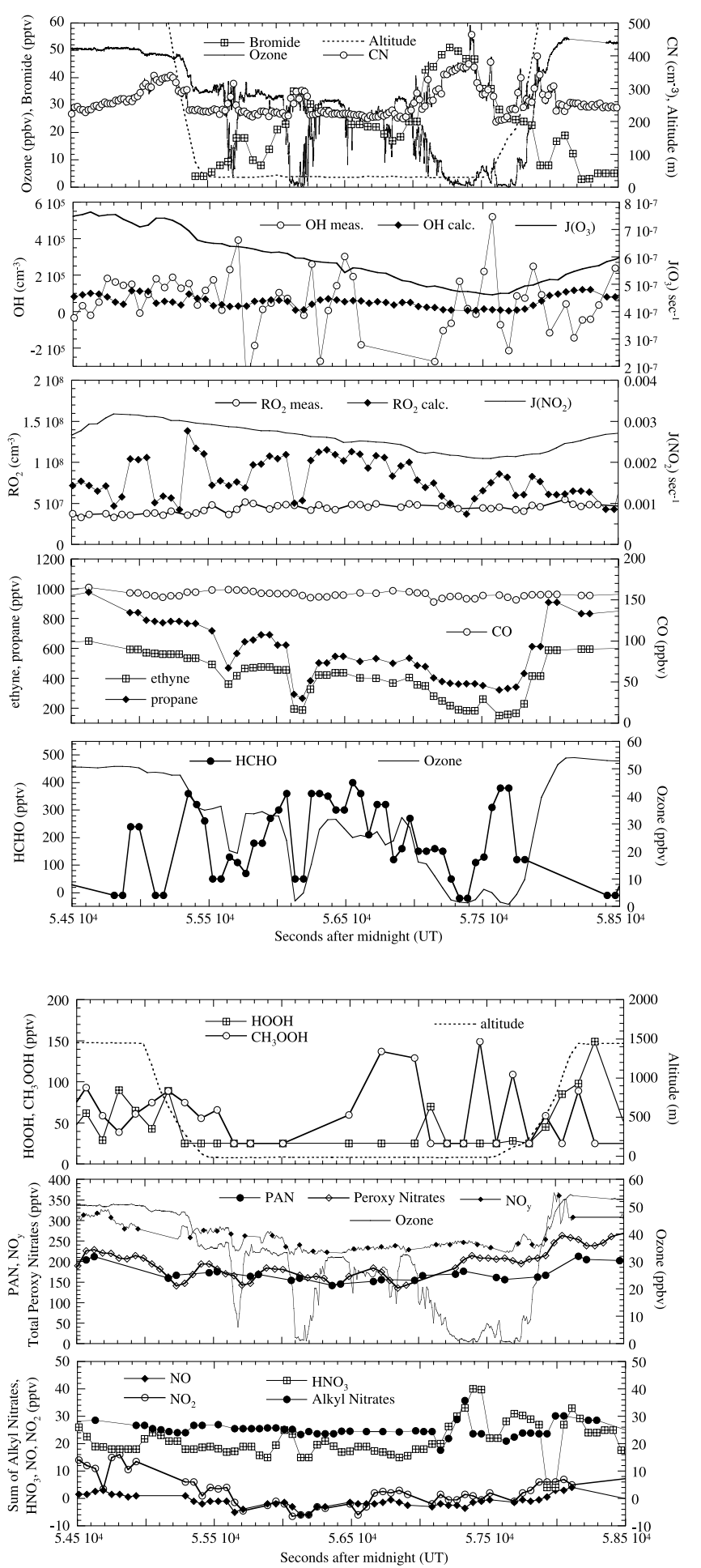

Figure 8. (a) Other constituent measurements for the low altitude leg over the Arctic Ocean for the 23 March flight. Bromide is soluble bromide measured by the mist chamber instrument and the detection limit is $\sim 2$ pptv. Soluble bromide was usually only measured when at low altitude. The data are from a 1 min average merged data file except for the top panel where ozone and $\mathrm{CN}$ are $1 \mathrm{~s}$ values. (b) As in Figure $8 \mathrm{a}$. The ozone and $\mathrm{NO}_{\mathrm{y}}$ data in the middle panel are at $10 \mathrm{~s}$ resolution. All other data are from the 1 min merged file. The detection limit of the $\mathrm{HOOH}$ and $\mathrm{CH}_{3} \mathrm{OOH}$ instruments is $\sim 25$ pptv. night or formation of $\mathrm{HNO}_{4}$ during the day and subsequent deposition to the surface or particles would be a sink for $\mathrm{NO}_{\mathrm{x}}$. The aircraft data do show that sources of HCHO from the surface are either much stronger at low insolation or that photochemical loss is weaker than those for $\mathrm{NO}_{\mathrm{x}}$ as would be implied from the Alert ground study in 1998 [Sumner and Shepson, 1999; Ridley et al., 2000].

\subsection{Arctic Ocean/Kane Basin/Smith Sound ODE of 27 April (Flight 34)}

[32] An extensive ODE was observed on this round-trip flight from Thule Air Base to $84^{\circ} \mathrm{N}$. Figure 9 shows the DIAL $\mathrm{O}_{3}$ observations and that the transit north was at stepped altitudes between 4 and $8 \mathrm{~km}$ until the descent for a 40 min $(\sim 240 \mathrm{~km})$ flight leg near $30 \mathrm{~m}$ altitude over the Arctic Ocean/Lincoln Sea. The portion of the flight track below $1500 \mathrm{~m}$ is shown in Figure 10. The southernmost portion was about $40 \mathrm{~km}$ northeast of Alert. The return to Thule was first at $5 \mathrm{~km}$ over the Robeson Channel separating northern Greenland and Ellesmere Island, followed by a low altitude leg which began near the northern edge of Kane Basin $\left(79.81^{\circ} \mathrm{N}\right)$ and continued south over Smith Sound to $77.67^{\circ} \mathrm{N}$ for a total distance of about $240 \mathrm{~km}$. Low to middle level clouds blocked the nadir view much of the time on the transit north except for a period when over Kane Basin and when just north of Alert before the descent. DIAL detected an ODE in both locations and another over North Baffin Bay for a brief interval of clearer skies prior to the landing approach to Thule. Indeed, the low level leg made on the return south was driven by the lidar observations made during the transit north. Although no depletion was observed at the Alert ground site for the previous 5-6 days,

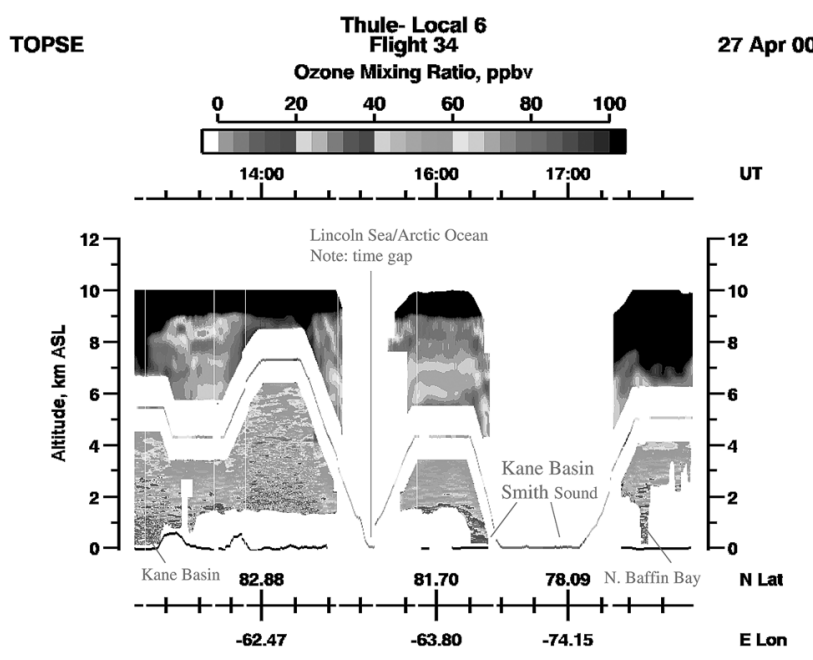

Figure 9. DIAL observations of ozone for the 27 April flight from Thule to the Arctic Ocean and return. Although clouds blocked the nadir view on much of the flight, ozone depletion was observed over Kane Basin on the north and south flight legs and also over N. Baffin Bay. Note the DIAL was off-line during much of the low altitude flight leg over the Arctic Ocean. See color version of this figure at back of this issue. 


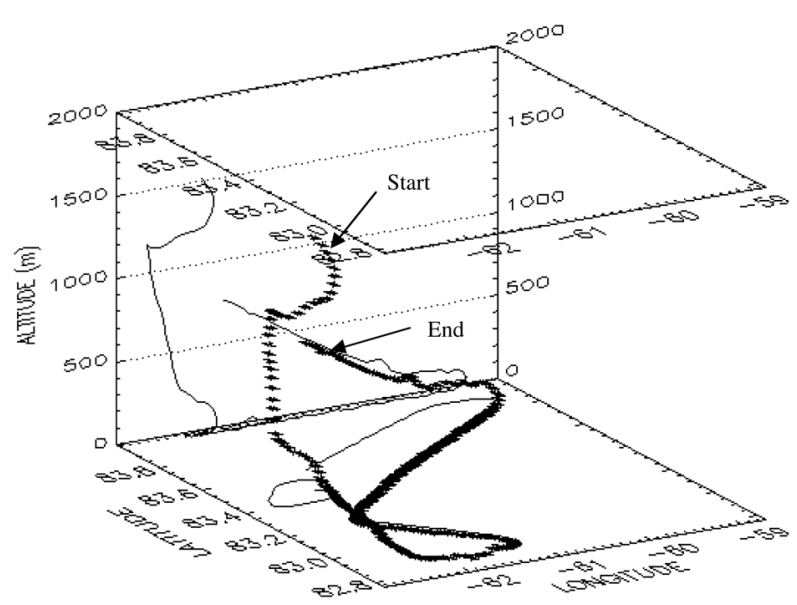

Figure 10. The flight track for the low altitude leg over the Arctic Ocean north of Alert on 27 April (Flight 34).

a MODE quickly moved over the ground site at Alert on this day and $\mathrm{O}_{3}$ remained below 5 ppbv at Alert for the succeeding 9-10 days $(\mathrm{K}$. Anlauf, private communication, 2001).
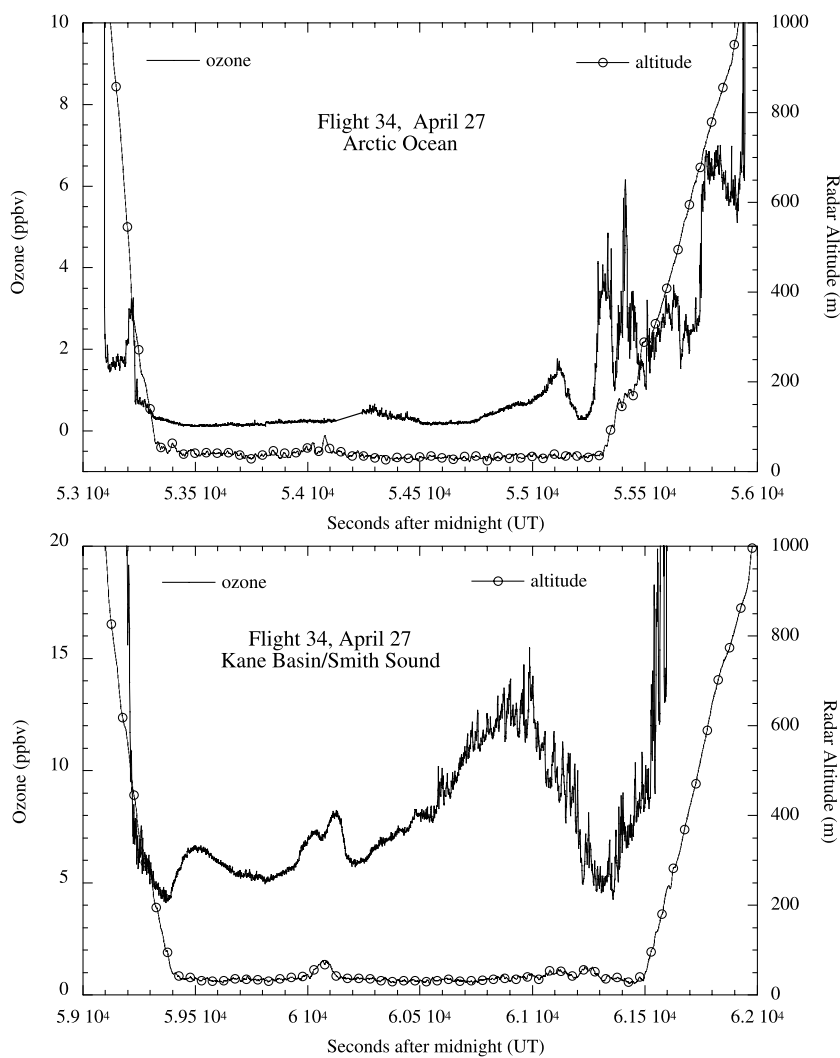

Figure 11. High resolution $(1 \mathrm{~s}, \sim 100 \mathrm{~m}) \mathrm{O}_{3}$ mixing ratios for the MODE over the Arctic Ocean and the PODE over Kane Basin and Smith Sound on 27 April. Minimum ozone in the MODE and PODE was 104 and 4100 pptv, respectively. In the lower panel, open water of the North Water Polynya was overflown starting near $60,480 \mathrm{~s}$. After $61,200 \mathrm{~s}$, less open water was overflown before the climb to higher altitudes.
[33] The $30 \mathrm{~m}$ altitude legs revealed a continuous MODE over the ocean north of Alert and a PODE over the Kane Basin/Smith Sound region as shown in Figure 11. Over the Arctic Ocean the minimum $\mathrm{O}_{3}$ was 104 pptv and it was fairly uniform until near the end of the leg. It appears that the aircraft was near the edge of the MODE just before ascent. In the second $30 \mathrm{~m}$ altitude leg a minimum $\mathrm{O}_{3}$ of 4.1 ppbv was found over the northern part of Kane Basin. No open leads were observed over the Arctic Ocean region, northern Kane Basin was also completely frozen, but the open water of the large North Water Polynya was overflown in Smith Sound. The heat source from the open water and increased turbulence is evident in the $\mathrm{O}_{3}$ data where greater variability was observed after $60,500 \mathrm{~s}$. The decrease in $\mathrm{O}_{3}$ near $61,200 \mathrm{~s}$ also corresponded to arrival over less open water.

[34] Back-trajectories for the $30 \mathrm{~m}$ altitude leg made north of Alert traced to the Arctic Ocean north of Siberia (5 days), or were confined to the ocean region (10 days). Those for the Kane Basin leg are shown in Figure 12 and revealed origins from the Arctic Ocean with flow essentially confined to the channel. Transit times from the Lincoln Sea to Kane Basin were $\sim 1$ day. Those for low altitude over North Baffin Bay (not shown) were a mix of air masses from the north and from the southeast over Greenland. The DIAL and in situ measurements and the trajectories are consistent with an ODE extending from at least $84^{\circ} \mathrm{N}$ over the Arctic Ocean and down the channel to North Baffin Bay or over a distance of $\sim 900 \mathrm{~km}$. Because $\mathrm{O}_{3}$ within the depleted air at

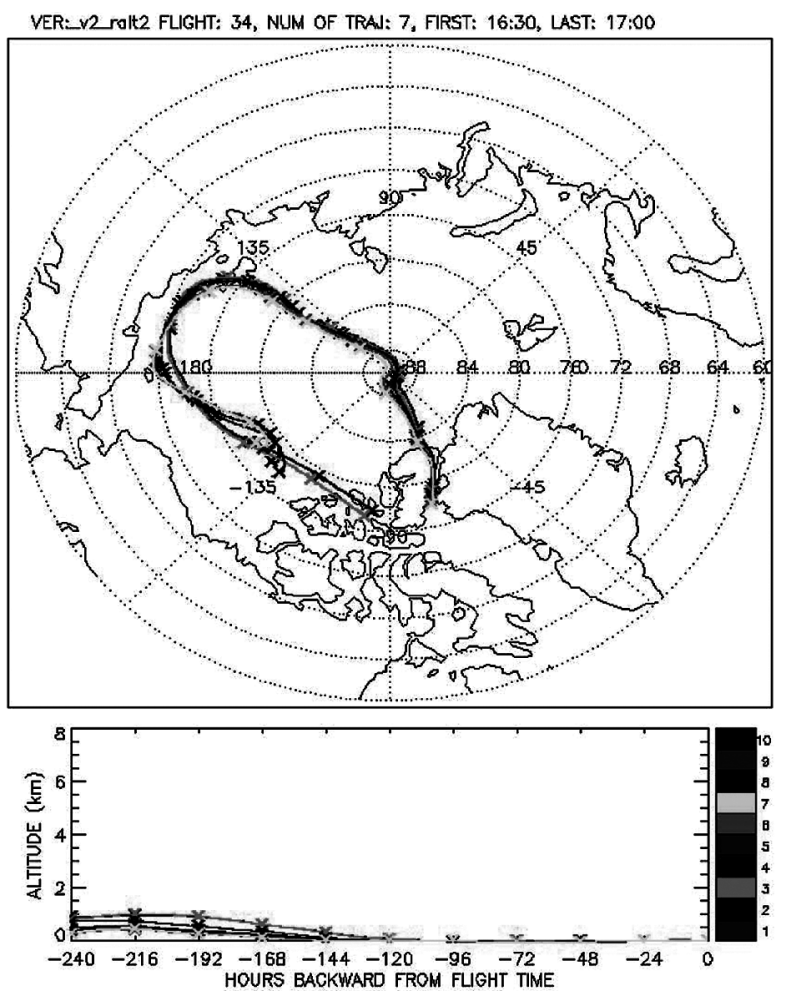

Figure 12. 10 day back-trajectories to the low altitude flight leg over Kane Basin and Smith Sound (lower panel of Figure 11) for the 27 April flight. See color version of this figure at back of this issue. 

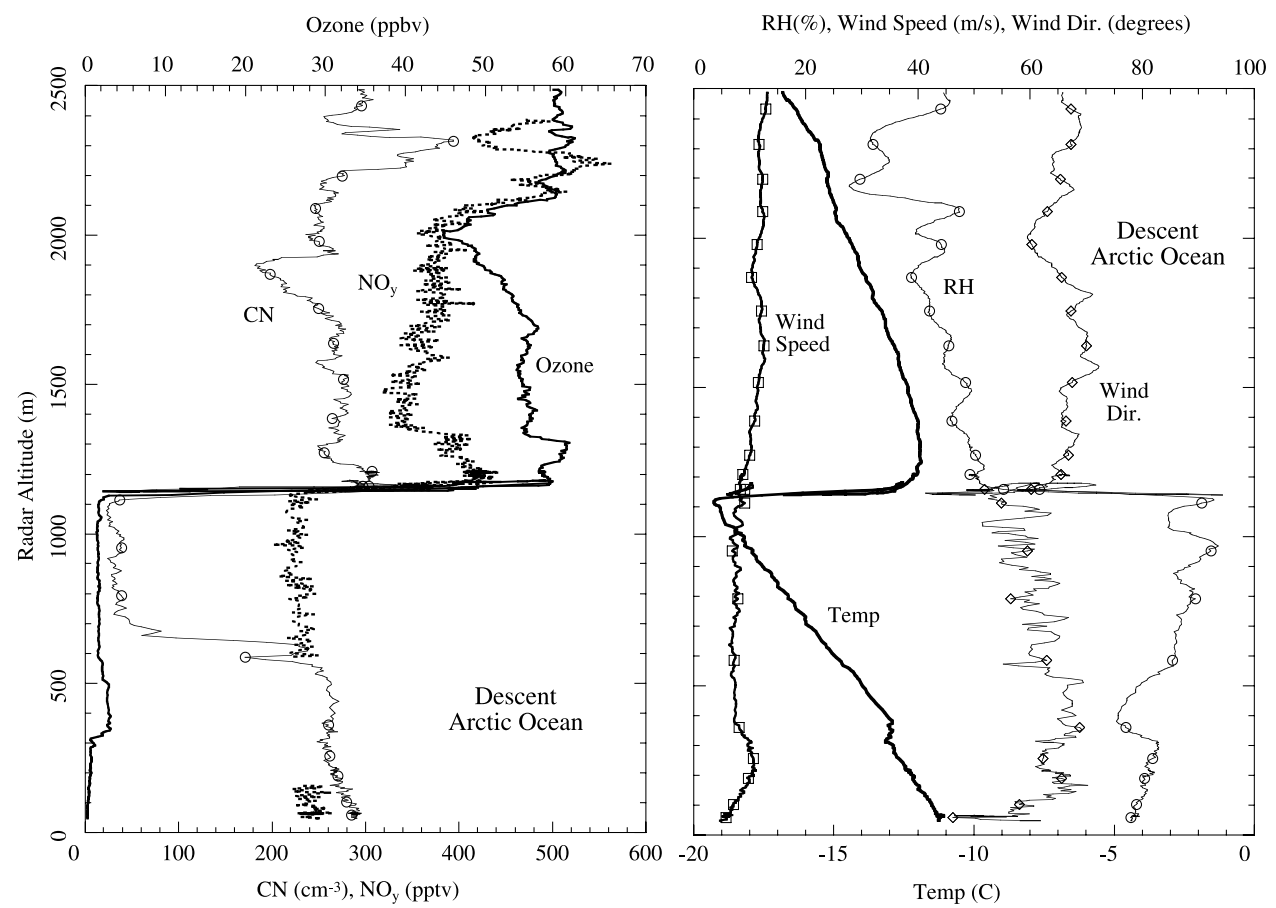

Ozone (ppbv)
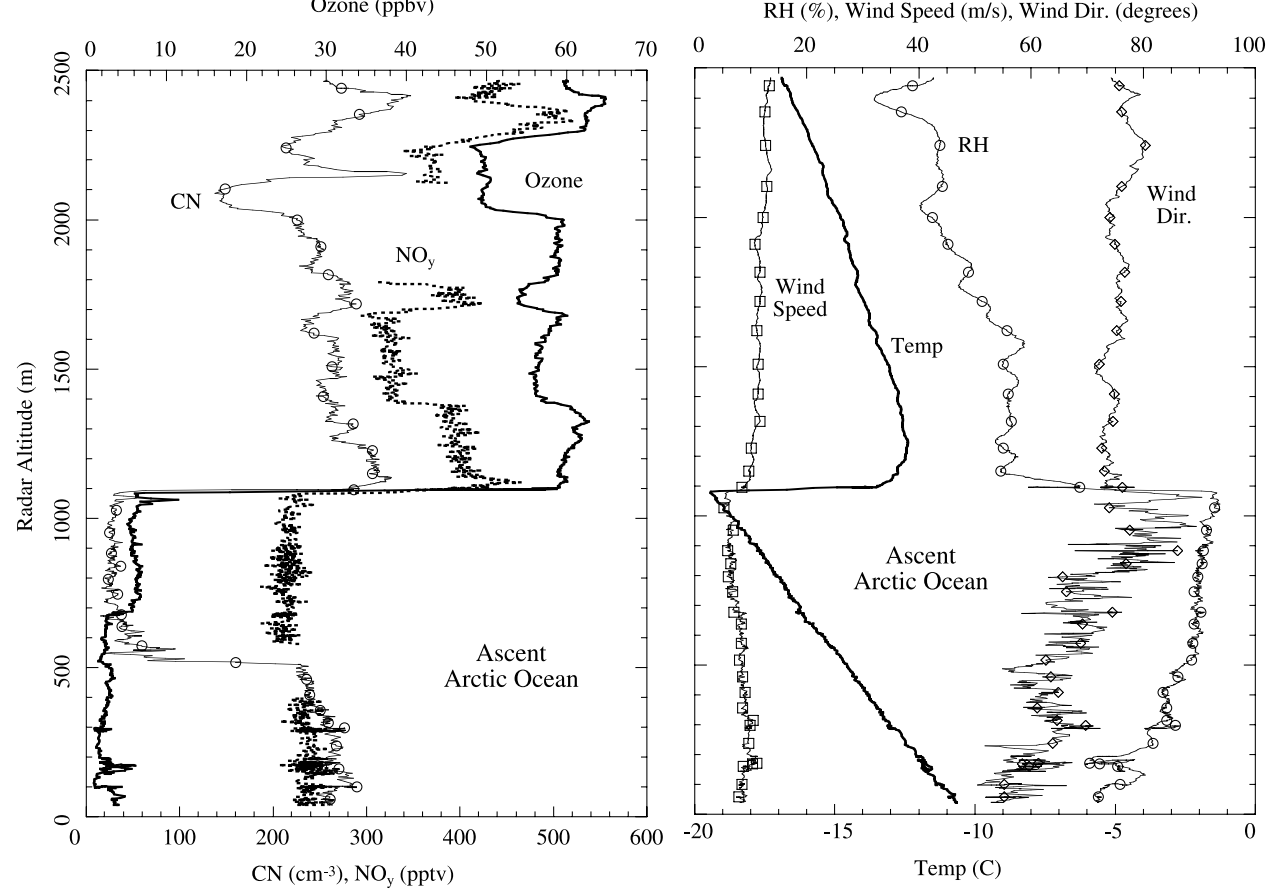

Figure 13. Profile data for the descent to and ascent from the $30 \mathrm{~m}$ altitude leg over the Arctic Ocean on the 27 April flight. Ozone depletion occurred throughout the surface layer capped by the strong temperature inversion at just above $1100 \mathrm{~m}$. All data are $1 \mathrm{~s}$ or $\sim 10-15 \mathrm{~m}$ vertical resolution.

$30 \mathrm{~m}$ altitude increased from north to south and because of changes in the vertical distribution to be discussed later, we consider it very likely that the ODE originated over the Arctic Ocean but survived export over the $900 \mathrm{~km}$ distance to the southern region of Smith Sound and North Baffin Bay. With our limited suite of measurements, we cannot tell unequivocally if significant halogen activity remained in these air masses.
[35] Profiles of some $1 \mathrm{~s}$ data for the descent and ascent over the Arctic Ocean are given in Figure 13. The ascent was $\sim 50 \mathrm{~km}$ to the northeast of the descent but the two soundings are remarkably similar both above and below the top of the surface layer demonstrating quite homogeneous conditions over the Ocean on this flight. In contrast to the flight of 23 March (cf. Figure 5), the air temperature near $30 \mathrm{~m}$ altitude was $10-12^{\circ} \mathrm{C}$ warmer and the surface 

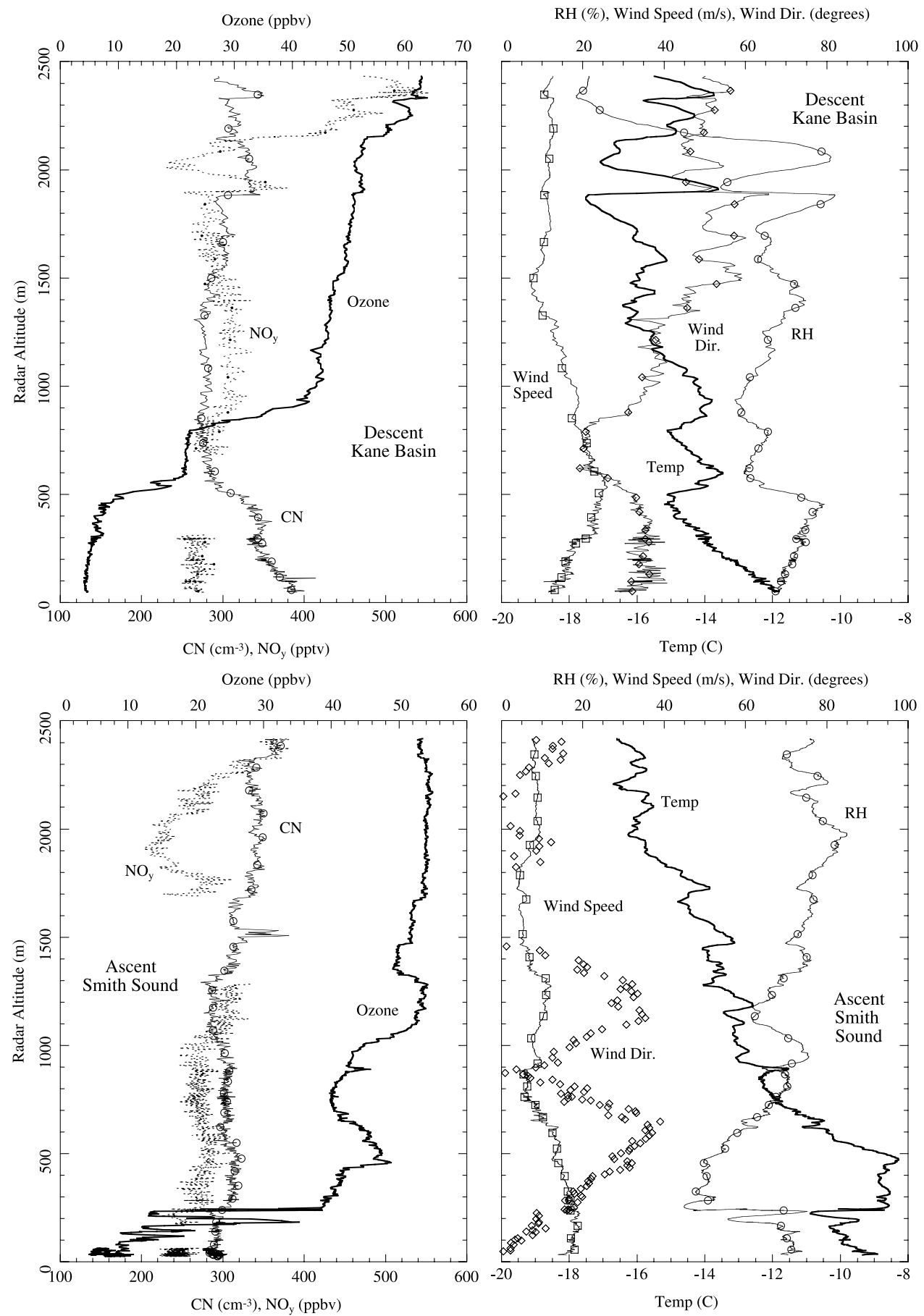

Figure 14. Profile data (1 s) for the descent to $30 \mathrm{~m}$ altitude over northern Kane Basin and ascent from $30 \mathrm{~m}$ over Smith Sound. The surface layer of ozone depletion decreased in altitude with decreasing latitude. Note the high wind speeds in the surface layer in both profiles.

layer was capped by a strong inversion aloft at $1100 \mathrm{~m}$ altitude. $\mathrm{O}_{3}$ decreased from near $60 \mathrm{ppbv}$ to below $2 \mathrm{ppbv}$ over an altitude change of only about $15 \mathrm{~m}$. A small difference between the two soundings was a weaker inversion in the descent profile near $350 \mathrm{~m}$ below which $\mathrm{O}_{3}$ was reduced further from 3 to less than $0.8 \mathrm{ppbv}$. Relative humidity increased while $\mathrm{CN}$ and $\mathrm{NO}_{\mathrm{y}}$ decreased significantly from above to below the inversion. $\mathrm{NO}_{\mathrm{y}}$ was distributed uniformly with altitude in the surface layer while $\mathrm{CN}$ was very low from the top of the inversion down to $500 \mathrm{~m}$ and uniform at $275 \mathrm{~cm}^{-3}$ at lower altitudes. In this case, unlike the 23 March flight, the change in $\mathrm{CN}$ with altitude in the surface layer was due to removal with cloud formation. On both the descent and ascent, a layer of thin clouds with bases near $500 \mathrm{~m}$ and tops at the $1100 \mathrm{~m}$ inversion were transited. Because the 
lapse rate was on the stable side of adiabatic, the uniformity of $\mathrm{NO}_{\mathrm{y}}$ throughout the surface layer depth and $\mathrm{CN}$ below cloud base suggest a well aged air mass, at least for constituents not readily reactive with halogens. This is consistent with the long residence time of 10 days or more implied by the trajectories.

[36] Soundings for the descent over Kane Basin and the ascent from Smith Sound are given in Figure 14. These soundings are generally consistent with erosion of both the depth of the surface layer and the strength of the temperature inversion. At Kane Basin lower altitude and weaker inversions denoted changes in depleted $\mathrm{O}_{3}$ at 500 and $700-800 \mathrm{~m}$. By Smith Sound the surface layer was only $250 \mathrm{~m}$ deep and $\mathrm{O}_{3}$ was highly structured indicative of further mixing. Only $7-20 \%$ of air from above the inversion would be required to increase $\mathrm{O}_{3}$ from the near-zero Arctic Ocean surface levels to the 4-12 ppbv range observed farther south. The fine structure was not observed in $\mathrm{CN}$ or $\mathrm{NO}_{y}$ since gradients across the inversion were found to be small on the ascent from Smith Sound.

[37] A notable difference on this flight compared to the flight of 23 March was the wind speed at low altitude. Previous work has suggested that relatively small to calm wind speeds are a typical characteristic of ODE formation [Bottenheim et al., 1990; Barrie and Platt, 1997]. In this case, wind speeds within the surface layer were remarkably high over the Arctic Ocean $(5-10 \mathrm{~m} / \mathrm{s})$ and even stronger $(10-25 \mathrm{~m} / \mathrm{s})$ over Kane Basin and Smith Sound. Over the latter region speeds were higher in the surface layer than above and the shear would promote mixing. Either the ODE formed earlier over the Arctic Ocean under light winds or a near calm condition is not a prerequisite of ODE formation. Indeed, the stronger winds and associated turbulence might promote ODE formation by pumping air through the upper layer of the snowpack and releasing active bromine and other constituents. It is also remarkable that the ODE was transported such a long distance of $900 \mathrm{~km}$ but remained relatively intact with respect to $\mathrm{O}_{3}$. Because the coastal elevations of Ellesmere Island and Greenland are relatively high and steep, the confinement of the flow by the channel likely aided this survivability.

[38] Other measurements made during the $30 \mathrm{~m}$ altitude legs over the Arctic Ocean and Kane Basin/Smith Sound are summarized in Figures $15 \mathrm{a}$ and $15 \mathrm{~b}$. In this case we have no information about the surface layer in the absence of $\mathrm{O}_{3}$ depletion over the Arctic Ocean but it is remarkable that mixing ratios of $\mathrm{PAN}, \mathrm{NO}_{\mathrm{y}}$ and $\mathrm{CO}$ were quite similar to those observed on the flight made nearly 1 month earlier on 23 March (Figure 8). Another feature is

Figure 15. (opposite) Constituent data emphasizing the low altitude legs over the Arctic Ocean and Kane Basin/ Smith Sound for the 27 April flight. All data are from the 1 min average merged file except $\mathrm{NO}_{\mathrm{y}}$, which is averaged over $10 \mathrm{~s}$. While at $4.5 \mathrm{~km}$ altitude, between 56,500 and $58,500 \mathrm{~s}$, large mixing ratios of many constituents were observed due to long-range transport from Eurasia. CO was over 240 ppbv and PAN was as large as 1700 pptv. Large $\mathrm{O}_{3}$ was observed to higher altitudes as shown in Figure 9.
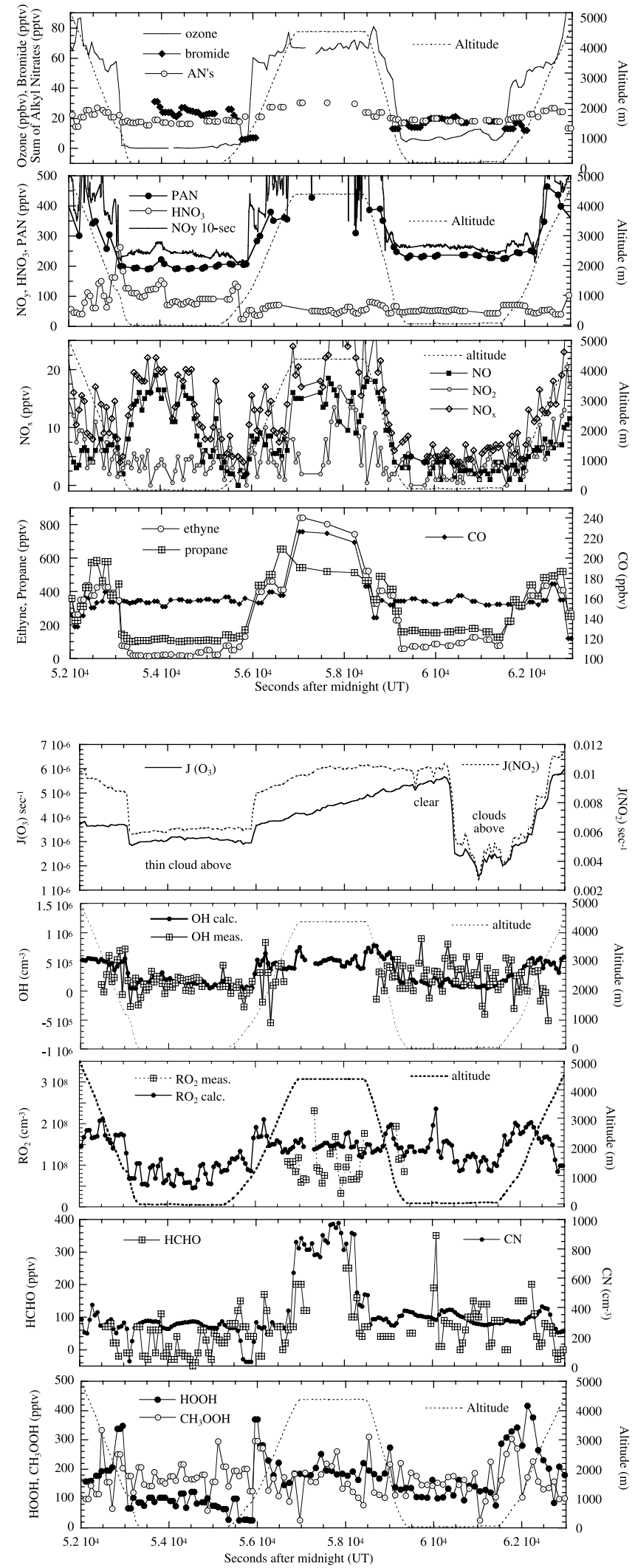

that many of the constituent mixing ratios were quite uniform within the surface layer over the ocean and farther south. This might be expected for longer lived species like $\mathrm{CO}, \mathrm{NO}_{\mathrm{y}}, \mathrm{PAN}$, and alkyl nitrates but it is also characteristic of the peroxides and to a lesser extent 
$\mathrm{HCHO}$ and $\mathrm{OH}$. The uniformity is also consistent with a well aged surface layer.

[39] Although PAN and $\mathrm{NO}_{\mathrm{y}}$ decreased within the surface layer compared to higher altitudes as observed on the 23 March flight, a striking difference from the earlier season ODE of 23 March is the behavior of $\mathrm{NO}_{\mathrm{x}}$. On descent over the Arctic Ocean into the MODE, $\mathrm{NO}_{\mathrm{x}}$, the $\mathrm{NO}_{\mathrm{x}} / \mathrm{NO}_{\mathrm{y}}$ ratio, and the $\mathrm{NO} / \mathrm{NO}_{2}$ ratio increased markedly to near $20 \mathrm{pptv}$, 0.08 , and 3-6.5, much larger than observed in the 23 March flight. These increases were quite sensitive to residual $\mathrm{O}_{3}$ being largest during the first three quarters of the leg but decreasing over the remainder of the leg as $\mathrm{O}_{3}$ increased to 1-4 ppbv (Figure 15a). During the leg farther south where $\mathrm{O}_{3}$ was always above 4 ppbv, $\mathrm{NO}_{\mathrm{x}}$ was similarly low with a median of $5.5 \mathrm{pptv}$ and the $\mathrm{NO} / \mathrm{NO}_{2}$ ratio decreased to approximately 0.7 . (This latter ratio is not very precise because the observed small mixing ratios were near the detection limit of the instrument.) $\mathrm{HNO}_{3}$ also apparently increased on descent over the Arctic Ocean to mixing ratios at $30 \mathrm{~m}$ altitude of $75-150 \mathrm{pptv}$ (median 92) considerably larger than observed in the surface layer of the 23 March flight and also larger than measured in the leg over Kane Basin/Smith Sound (median $51 \mathrm{pptv}$ ). However, a close examination of Figure 15a reveals spikes of $\mathrm{HNO}_{3}$ to 260 (near 53,000 s) and 145 pptv (near 55,500 s) coincident with transiting the cloud layer between 500 and $1100 \mathrm{~m}$ discussed previously. Since the $\mathrm{HNO}_{3} / \mathrm{NO}_{\mathrm{y}}$ ratio alone exceeded unity, and because the $\mathrm{NO}_{\mathrm{y}}$ inlet was aft-facing, the spikes were not due to increases in gaseous $\mathrm{HNO}_{3}$. It is likely that the in-cloud signal required some time for the inlet to recover so that the data is suspect as gaseous $\mathrm{HNO}_{3}$ for the Arctic Ocean leg.

[40] The increase of $\mathrm{NO}_{\mathrm{x}}$ in the Arctic Ocean MODE is consistent with a stronger surface source from the snow surface driven by sunlight [Honrath et al., 2000a] or with reduced loss processes associated with formation of reservoirs that could be deposited to the surface. By the time of this flight, and in spite of the thin cloud layer between 500 and $1100 \mathrm{~m}$, insolation was considerably stronger and the surface layer was not as stable as in the 23 March flight. For example, on this flight $\mathrm{J}\left(\mathrm{NO}_{2}\right)$ and $\mathrm{J}\left(\mathrm{O}_{3}\right)$ were nearly 3 and 6 times higher over the Arctic Ocean. Even if bromine chemistry remained active in this MODE, the observed increase in $\mathrm{NO}_{\mathrm{x}}$ would be consistent with a decreased loss rate by curtailment of the formation of $\mathrm{BrONO}_{2}$ and subsequent surface deposition. With $\mathrm{O}_{3}$ near $0.4 \mathrm{ppbv}$, $\mathrm{BrO}_{\mathrm{x}}(=\mathrm{Br}+\mathrm{BrO})$ and $\mathrm{NO}_{\mathrm{x}}$ partitioning would favor $\mathrm{Br}$ and $\mathrm{NO}$, as shown by the $\mathrm{NO} / \mathrm{NO}_{2}$ ratio derived from Figure 15a. Formation and deposition of $\mathrm{HNO}_{4}$ could also be reduced with the increase in the $\mathrm{NO} / \mathrm{NO}_{2}$ ratio. With continuous sunlight at these latitudes, loss of $\mathrm{NO}_{\mathrm{x}}$ via $\mathrm{N}_{2} \mathrm{O}_{5}$ formation and deposition would not be a factor. The loss of $\mathrm{NO}_{\mathrm{x}}$ via $\mathrm{HNO}_{3}$ formation would also be too slow. At the low concentration of $\mathrm{OH}$ at $30 \mathrm{~m}$ altitude shown in Figure 15b, the time constant for formation of the acid would be just under 1 day. Similar suggestions have been made from observations of $\mathrm{NO}_{\mathrm{x}}$ made during a MODE at Alert [Ridley and Orlando, 2002]. In contrast, by the time the air mass had traveled farther south and suffered some mixing so that $\mathrm{O}_{3}$ was not below 4 ppbv, removal of $\mathrm{NO}_{\mathrm{x}}$ by changes in partitioning to larger fractions of $\mathrm{BrO}$ and $\mathrm{NO}_{2}$ would increase $\mathrm{BrONO}_{2}$ and
$\mathrm{HNO}_{4}$ formation and hence deposition to the surface. It is also possible that surface sources were smaller or the net effect of emissions decreased by the stronger winds at lower latitudes. Significant emissions would not be expected from the polynya described previously.

[41] The increase of the $\mathrm{NO} / \mathrm{NO}_{2}$ ratio in the MODE is qualitatively expected. The ratio is given by $\mathrm{NO} / \mathrm{NO}_{2} \cong$ $\mathrm{J}\left(\mathrm{NO}_{2}\right) /\left\{\mathrm{k}_{\mathrm{NO}}\left[\mathrm{O}_{3}\right]+\mathrm{k}_{\mathrm{RO} 2}\left[\mathrm{RO}_{2}\right]+\mathrm{k}_{\mathrm{BrO}}[\mathrm{BrO}]\right\}$ where the k's are the rate constants for oxidation of $\mathrm{NO}$ to $\mathrm{NO}_{2}$ by the subscripted constituents. Normally ozone is sufficiently large that the first term in the denominator dominates the ratio. With no $\mathrm{RO}_{2}$ or $\mathrm{BrO}$ present, the ratio would be expected to increase to $\sim 59$ for the observed median ozone $(0.38 \mathrm{ppbv})$, temperature $\left(-10.9^{\circ} \mathrm{C}\right)$, and $\mathrm{J}\left(\mathrm{NO}_{2}\right)(6.2 \times$ $\left.10^{-3} \mathrm{~s}^{-1}\right)$ of the Arctic Ocean MODE. For the second low altitude leg, and using the median $\mathrm{O}_{3}$ of $7.1 \mathrm{ppbv}$ for the entire leg, the ratio would be $\sim 5$ and $\sim 2.5$ for the clear and overhead cloud regions shown in the top panel of Figure 15b. Since the observed ratio over the Arctic Ocean was much lower than 59 , ranging from 3 to 6.5 , median 3.3, $\mathrm{RO}_{2}$ and/or $\mathrm{BrO}$ must have been present. Unfortunately the $\mathrm{RO}_{2}$ instrument did not provide data for the low altitude leg over the ocean. However, if we use the steady state calculation of $\mathrm{RO}_{2}$ [Cantrell et al., 2002] of $\sim 7 \times$ $10^{7} \mathrm{~cm}^{-3}$ (Figure $15 \mathrm{~b}$ ) the expected ratio would be $\sim 8$ which is not much larger than the maximum observed of 6.5. To obtain ratios as low as the median of $3.3, \mathrm{RO}_{2}$ would have to be increased to $2 \times 10^{8} \mathrm{~cm}^{-3}$, which suggests the need for radical sources from reactive halogen chemistry that were not considered in the model. Without increasing $\mathrm{RO}_{2}, \sim 2$ pptv of $\mathrm{BrO}$ would be required to give the median $\mathrm{NO} / \mathrm{NO}_{2}$ ratio. Clearly the absence of the $\mathrm{RO}_{2}$ data does not allow us to ascertain whether halogen activation remained in the MODE from the $\mathrm{NO} / \mathrm{NO}_{2}$ ratio with any certainty. In the leg over Kane Basin/Smith Sound there are several $\mathrm{RO}_{2}$ measurements just near the start of the leg (Figure 15b). Using $\mathrm{RO}_{2}$ of $(1-2) \times 10^{8}$ $\mathrm{cm}^{-3}$, the expected ratio would be $\sim 3$ and $\sim 1.5$ for the clear and cloudy periods. This appears to be larger than the median of 0.7 observed over the whole leg, suggesting the need for active BrO. However, as stated previously, the error in the observed median is simply too large (a factor of 2) to give a meaningful value for the mixing ratio of BrO.

[42] $\mathrm{OH}$ measurements for the two low altitude legs are also shown in Figure 15b. Ambient levels remained near the instrument detection limit. The median over the Arctic Ocean leg was $1.3 \times 10^{5} \mathrm{~cm}^{-3}$ and over the Kane/Smith leg was $3.0 \times 10^{5} \mathrm{~cm}^{-3}$, both considerably larger than occurred during the earlier season flight of 23 March (cf. Figure 8a). Production of $\mathrm{OH}$ in the ODEs remained limited by the low $\mathrm{O}_{3}$ and also, as shown in the figure, the small mixing ratios of HCHO. In both legs the measurements are in good agreement with the steady state calculation, implying that sources of $\mathrm{OH}$ precursors like HONO [Zhou et al., 2001] from the snow surface did not survive to the $30 \mathrm{~m}$ altitude of the measurements and that possible sources from halogen activity were small. Although $\mathrm{J}\left(\mathrm{O}_{3}\right)$ changed by a factor of 2 between the clear and cloudy regions of Kane Basin/Smith Sound, the lack of change in the measurements or calculation is mostly because $\mathrm{O}_{3}$ was low, and therefore photolysis was a minor source of $\mathrm{OH}$. Although $\mathrm{RO}_{2}$ data 


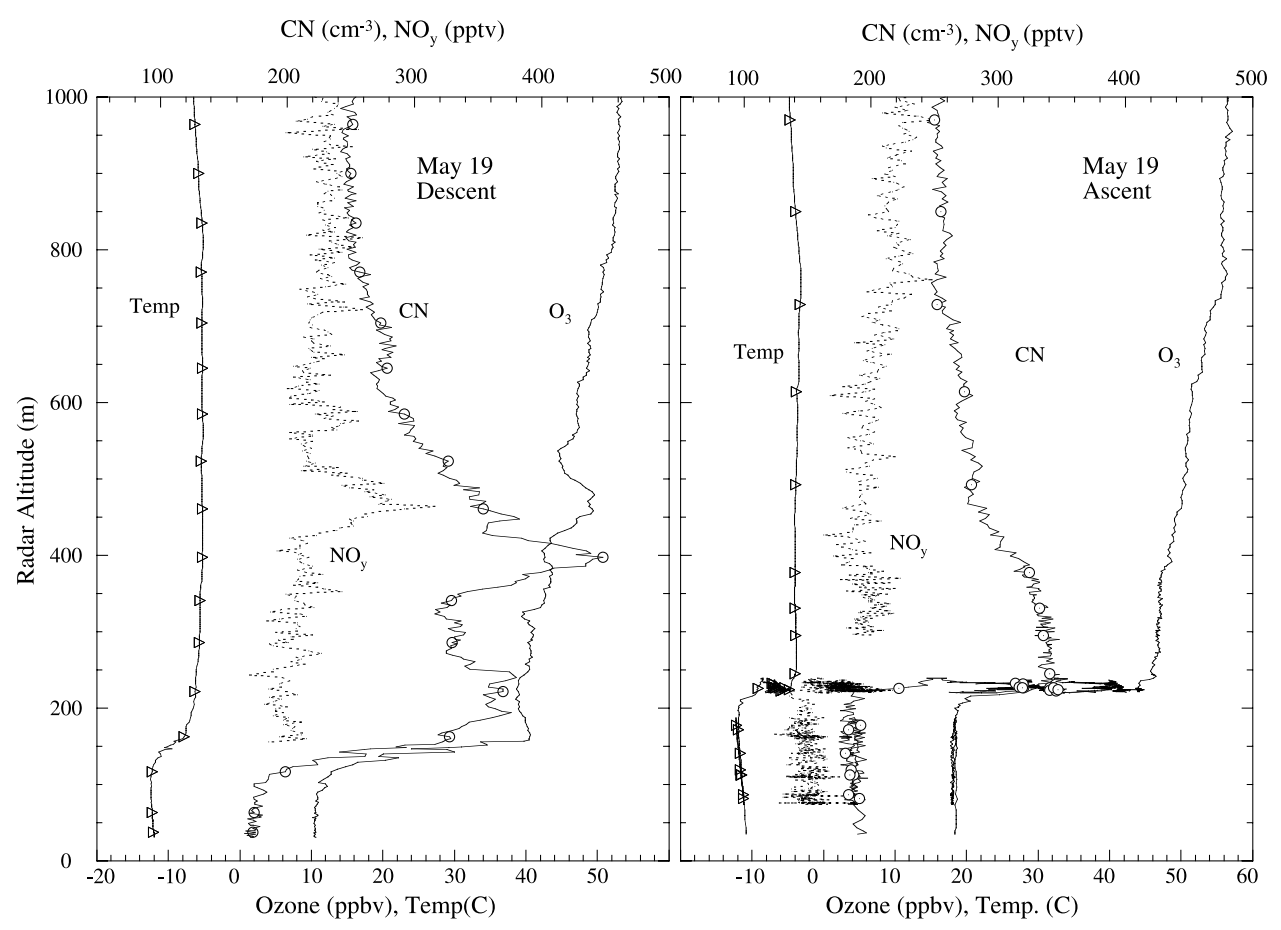

Figure 16. Profile data $(1 \mathrm{~s})$ for the descent to $30 \mathrm{~m}$ altitude and ascent at $85^{\circ} \mathrm{N}$ over the Arctic Ocean, $280 \mathrm{~km}$ north of Alert, on 19 May. Ozone was partially depleted in a shallow surface layer of $150-230 \mathrm{~m}$ thickness. On ascent, the data are "fuzzy" near the top of the surface layer due to horizontal variability. The aircraft flew at $230 \mathrm{~m}$ for $\sim 5 \mathrm{~min}$ before continuing to ascend.

are sparse, the steady state concentrations when combined with the maximum $\mathrm{NO}$ mixing ratio of 20 pptv over the Arctic Ocean would yield a rate of production of $\mathrm{O}_{3}$ of only $0.15 \mathrm{ppbv} / \mathrm{d}$. Clearly, photochemical recovery of $\mathrm{O}_{3}$ would be very slow and not competitive with ventilation of the surface layer from higher altitudes or laterally from a nondepleted surface layer regions [Ridley and Orlando, 2002].

[43] The behavior of other constituents relative to altitudes above the surface layer or compared to the behavior in the earlier season ODEs of 23 March (Flight 21) were generally similar. The representative hydrocarbons, ethyne and propane, show a strong reduction in the MODE and PODE relative to the abundance at higher altitudes. The increase in the PODE over Kane Basin and Smith Sound is easily accounted for by small amounts of mixing from above which was discussed previously for ozone. In spite of the seasonal trend of decreasing hydrocarbons with time, the reductions relative to nondepleted air masses of ethyne to a median of 24 pptv and propane to $107 \mathrm{pptv}$ in the Arctic Ocean MODE are much stronger than the reductions that occurred on the 23 March flight. This MODE was either aged considerably more prior to observation or the halogen radical concentrations were much larger. That soluble bromide increased to a median of 24 pptv but only to about $1 / 2$ the maximum observed in the MODE of 23 March supports a longer age rather than more intense halogen activation in agreement with the trajectory information. Like the 23 March case, median HCHO of 25 pptv was very low in the MODE and remained relatively low at a median of 85 pptv in the Kane Basin and Smith Sound surface layer.
Again $\mathrm{HOOH}$ was small at a median of 87 pptv in the MODE and slightly larger at a median of $127 \mathrm{pptv}$ in the PODE. $\mathrm{CH}_{3} \mathrm{OOH}$ was more uniform at a median of 175 and 151 pptv in the MODE and PODE.

\subsection{Arctic Ocean PODE of 19 May (Flight 40)}

[44] This late spring season ODE was investigated during a $120 \mathrm{~km}$ long $30 \mathrm{~m}$ altitude leg flown from $64.7^{\circ} \mathrm{W}$ due east to $53.3^{\circ} \mathrm{W}$ at $85^{\circ} \mathrm{N}(280 \mathrm{~km}$ north of Alert) over the Arctic Ocean. Insolation was of course continuous and at a higher solar elevation of $25^{\circ}$ during the low altitude leg. The region was first overflown at high altitude, and although no significant clouds were present, DIAL only provided periodic hints but not conclusive evidence of ODEs. Descent and ascent profiles from faster response instruments are shown in Figure 16 for altitudes below $1000 \mathrm{~m} . \mathrm{O}_{3}$ was depleted to a minimum of $10.2 \mathrm{ppbv}$ on descent and to only $19 \mathrm{ppbv}$ on ascent below weak inversions aloft at 150 and $230 \mathrm{~m}$, respectively. The shallowness of the partially depleted surface layer likely prevented DIAL from conclusive detection. Winds in both the ascent and descent regions in the surface layer were quite uniform with altitude and relatively high at $6-10 \mathrm{~m} / \mathrm{s} . \mathrm{O}_{3}, \mathrm{CN}$, and $\mathrm{NO}_{\mathrm{y}}$ were also uniform with altitude in the surface layer and decreased in concert below the inversions, rather typical behavior, and indicative of well mixed conditions. $\mathrm{O}_{3}$ and $\mathrm{NO}_{\mathrm{y}}$ were also remarkably uniform above the inversion to $1000 \mathrm{~m}$ and not correlated with the several hundred meter thick layer of elevated $\mathrm{CN}$ above the inversion. As in previous surface layer legs, median relative humidity was high at $77 \%$ and air temperature (median of $-11.4^{\circ} \mathrm{C}$ ) was only marginally 

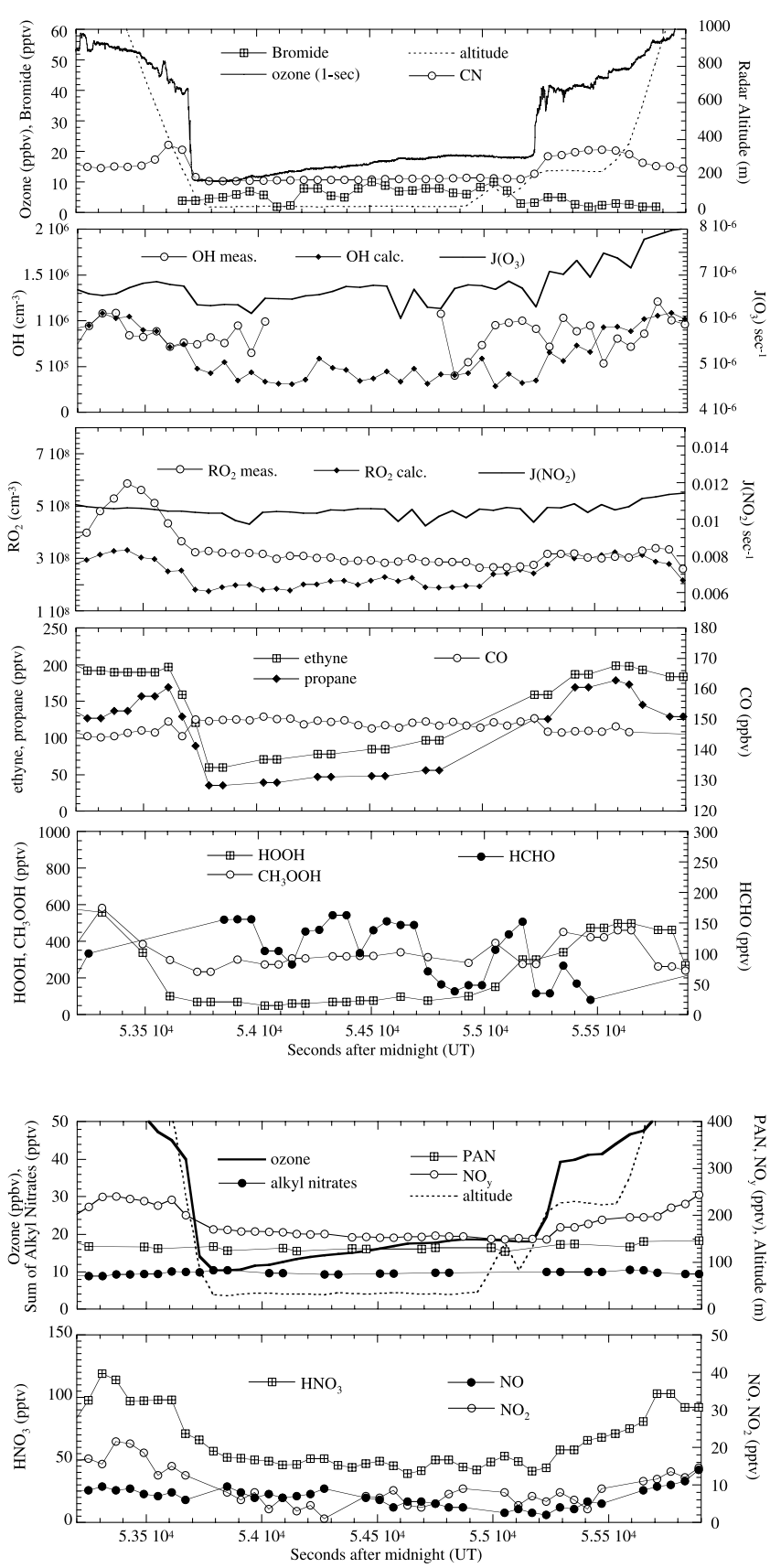

Figure 17. Constituent mixing ratios from the $1 \mathrm{~min}$ merged database for the $30 \mathrm{~m}$ altitude leg over the Arctic Ocean on 19 May. $\mathrm{O}_{3}$ data in the top panel are $1 \mathrm{~s}$ measurements.

warmer than the previous flight of 27 April. Numerous open leads were observed in the ice pack that would promote vertical mixing.

[45] Trajectories for this flight leg are not shown, but they were very similar to those presented for the flight of 21 March (cf. Figure 6). That is flow was up the channel between Ellesmere Island and Greenland for at least the previous 4 days. The transit time from mid-Baffin Bay to the flight region was $\sim 4$ days. (Examination of trajectories to this region of the Arctic Ocean over the 2000 spring period revealed that alternation between sources of long residence over the Arctic Ocean versus flow up the channel from the south was reasonably common.) In this case there is direct evidence that ODEs were not present at lower latitudes. DIAL detected no depleted air on the transit north and south under cloud-free conditions. A $30 \mathrm{~m}$ altitude leg made over the Kane Basin/Smith Sound region showed NODE conditions confirming the absence of a very shallow depleted surface layer that would perhaps not be detected by DIAL (cf. Figure 2b). As for the 21 March flight, we suspect that mixing between a depleted Arctic Ocean air mass with flow of undepleted air from the south was the reason for the partial ozone depletion observed during the flight.

[46] The behavior of constituents during the low altitude leg is shown in Figures $17 \mathrm{a}$ and $17 \mathrm{~b} . \mathrm{O}_{3}$ increased from 10 to $19 \mathrm{ppbv}$ as the aircraft proceeded east, but there was no significant small-scale structure. Qualitatively the behavior of most species is similar to observations from previous cases of partial ozone depletion (medians over the $30 \mathrm{~m}$ leg are given in parentheses): elevated bromide (6.8 pptv) but relatively small mixing ratios compared to other cases; depleted ethyne (78 pptv) and propane (47 pptv); elevated HCHO (138 pptv) but highly variable mixing ratios compared to other constituents; uniform and low mixing ratios of PAN (129 pptv), $\mathrm{HNO}_{3}$ (48 pptv), alkyl nitrates (9.6 pptv), $\mathrm{NO}_{\mathrm{x}}(12.3 \mathrm{pptv})$ and $\mathrm{NO}_{\mathrm{y}}(158 \mathrm{pptv})$. Most constituents $\left(\mathrm{HOOH}, \mathrm{CH}_{3} \mathrm{OOH}, \mathrm{NO}_{\mathrm{x}}, \mathrm{HNO}_{3}, \mathrm{NO}_{\mathrm{y}}, \mathrm{PAN}\right.$, ethyne, propane, and $\mathrm{CN}$ ) showed a decline in the surface layer relative to altitudes above the inversion. Alkyl nitrates were invariant and $\mathrm{CO}$ showed a slight increase. The clear winter/ spring seasonal decline in the representative hydrocarbons and alkyl nitrates is evident through comparison of data with the 23 March flight (Figures 8a and 8b) [Blake et al., 2002]. $\mathrm{HOOH}$ at a median of 69 pptv was similar to mixing ratios observed in earlier PODE cases but $\mathrm{CH}_{3} \mathrm{OOH}$ at 302 pptv was $\sim 50 \%$ larger than observed in earlier cases. For the latter peroxide, the increase is consistent with the seasonal trends discussed by Snow et al. [2002].

[47] The greatest difference from the previous cases is seen in the $\mathrm{OH}$ and $\mathrm{RO}_{2}$ data as might be expected for higher actinic flux illustrated by $\mathrm{J}\left(\mathrm{O}_{3}\right)$ and $\mathrm{J}\left(\mathrm{NO}_{2}\right)$ in Figure 17a and the fact that although $\mathrm{O}_{3}$ was reduced it was still relatively high at $10-19$ ppbv. $\mathrm{J}\left(\mathrm{O}_{3}\right)$ was almost twice as large as in the previous flight of 27 April. Median observed $\mathrm{OH}$ was $4.1 \times 10^{5} \mathrm{~cm}^{-3}$ significantly larger than seen before in this region or in the Kane Basin region of flight 34. $\mathrm{RO}_{2}$ at a median of $3 \times 10^{8} \mathrm{~cm}^{-3}$ was also larger. However, the largest change was in the comparison with the steady state model. Although the model calculated concentration increased from previous flight examples as expected, measured $\mathrm{OH}$ was a factor of 2 larger than calculated. Measured $\mathrm{RO}_{2}$ was 1.5 times larger than calculated at 30 $\mathrm{m}$ altitude but in good agreement at slightly higher altitudes near $230 \mathrm{~m}$. Thus in contrast to the previous 27 April flight over the Arctic Ocean where MODE conditions prevailed, there is now some evidence that the model is missing sources of $\mathrm{OH}$ and perhaps $\mathrm{RO}_{2}$ as well. As discussed previously, the model does not contain reactive halogen chemistry that could provide additional $\mathrm{HO}_{\mathrm{x}}$ sources nor does it contain a source of HONO from the surface as observed by Zhou et al. [2001], Dibb et al. [2002], and Honrath et al. [2002]. 


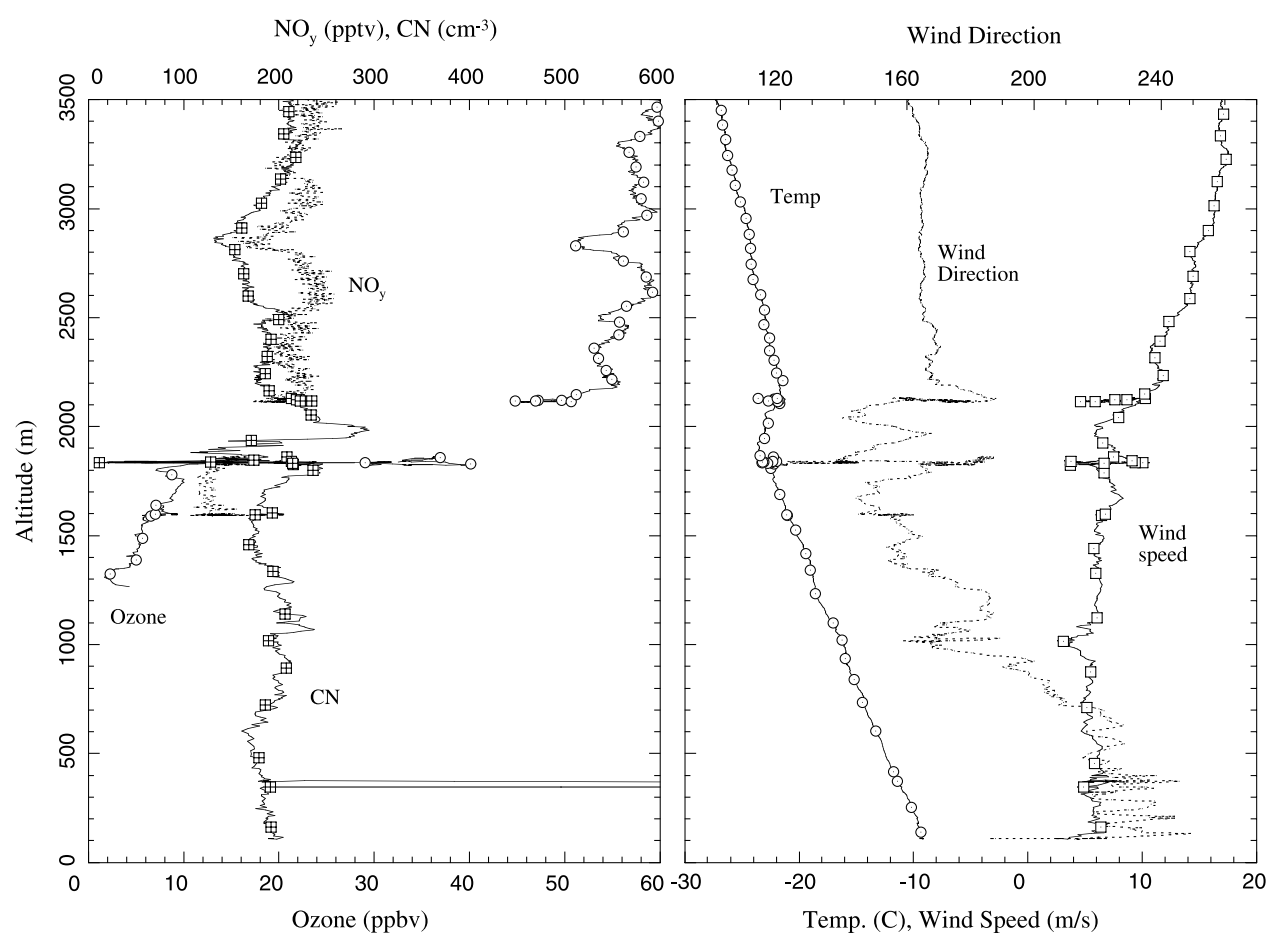

Figure 18. Vertical distributions of $\mathrm{CN}, \mathrm{NO}_{\mathrm{y}}, \mathrm{O}_{3}$, temperature, and winds (all $1 \mathrm{~s}$ data) observed on takeoff from Thule Air Base at the beginning of Flight 41. The ozone depletion that was mapped across Baffin Bay by DIAL (Figure 3) was capped near Thule at $1800 \mathrm{~m}$ by a weak temperature inversion. The depletion event was not present in the area near Thule 2 days earlier.

[48] Compared to the Arctic Ocean MODE of 27 April where the local ozone production rate was only $\sim 0.15$ ppbv/d, the enhanced $\mathrm{RO}_{2}$ of at least a factor of 10 measured on this flight but with a smaller NO mixing ratio (median $6.5 \mathrm{pptv}$ ) yields a rate of $1.5 \mathrm{ppbv} / \mathrm{d}$. Even this larger rate of production, if applicable throughout the surface layer, would likely not compete with the increase in $\mathrm{O}_{3}$ provided by the horizontal mixing suggested by the trajectory information.

\subsection{Baffin Bay ODE of 22 May (Flight 41)}

[49] The final example is a later spring ODE mapped by DIAL during the penultimate TOPSE flight from Thule to Winnipeg. On the flight made 2 days earlier no ODE was observed in the region, so it either formed rapidly or was the result of transport from another location. Figure 3, given previously, shows that the ODE extended over $\sim 600 \mathrm{~km}$ from Thule across Baffin Bay to the east side of Baffin Island. Depletion was observed to unusually high altitude, $\sim 2400 \mathrm{~m}$, to the west of Thule. More often ODEs were restricted to lower altitudes as summarized in Table 1. Because of bad weather in Churchill, which was the reason for landing in Winnipeg, time could not be spent investigating the ODE in situ. However, a few instruments were operating shortly after takeoff and profiles are shown in Figure 18. On takeoff $\mathrm{O}_{3}$ was apparently reduced up to 1800 $\mathrm{m}$ coincident with the location of a quite weak temperature inversion aloft. (Other data exhibit discontinuities near 1800 and $2200 \mathrm{~m}$ but these resulted from horizontal rather than vertical changes because the aircraft was vectored by air traffic control to maintain these altitudes for a number of minutes before clearance was given to climb higher.) $\mathrm{O}_{3}$ increased from a minimum of 1.8 ppbv near $1300 \mathrm{~m}$ to 9 ppbv just below the inversion aloft. Across the inversion $\mathrm{O}_{3}$ increased to over $40 \mathrm{ppbv}$ in a few meters of altitude increase. Both the $\mathrm{O}_{3}$ and $\mathrm{NO}_{\mathrm{y}}$ instruments were in an automatic zeroing mode for a short time between 1900 and $2100 \mathrm{~m}$ so it is not known if the structure seen in $\mathrm{CN}$, wind speed, and other variables at this time was reflected in $\mathrm{O}_{3}$. There was little change in $\mathrm{CN}$ across the inversion but a substantial increase in $\mathrm{NO}_{\mathrm{y}}$ of $\sim 90$ pptv occurred. Wind speeds were moderate at $\sim 6 \mathrm{~m} / \mathrm{s}$ below the inversion.

[50] Back-trajectories for low altitude over Baffin Bay are shown in Figure 19. They indicate a source from almost due west or north of the Beaufort Sea 3-4 days earlier. They also indicate a residence time over the Ocean for at least another 6 days allowing ample opportunity for the depletion to occur. Corroborating evidence for long-range transport from the western Arctic Ocean is provided by the flight made 2 days earlier (19 May) from Thule over the channel between Greenland and Ellesmere Island to north of Alert and return. Skies were clear below the flight track and no ODE was detected by DIAL south of the Arctic Ocean over the channel or north Baffin Bay. North of Alert a PODE was found during a $30 \mathrm{~m}$ altitude leg over the ocean (cf. Figure 2a), but one over the Kane Basin/Smith Sound region and the landing approach to Thule revealed no ozone depletion in agreement with DIAL. At this time, trajectories to the Alert region and Kane Basin/Baffin Bay were from the south with a cyclonic loop over parts of Greenland. Thus there is no suggestion that the ODE over North Baffin Bay on 22 May originated from the Arctic 
VER:-V2 rolt2 FLIGHT: 41, NUM OF TRA: 5, FIRST: 13:15, LAST: 13:35
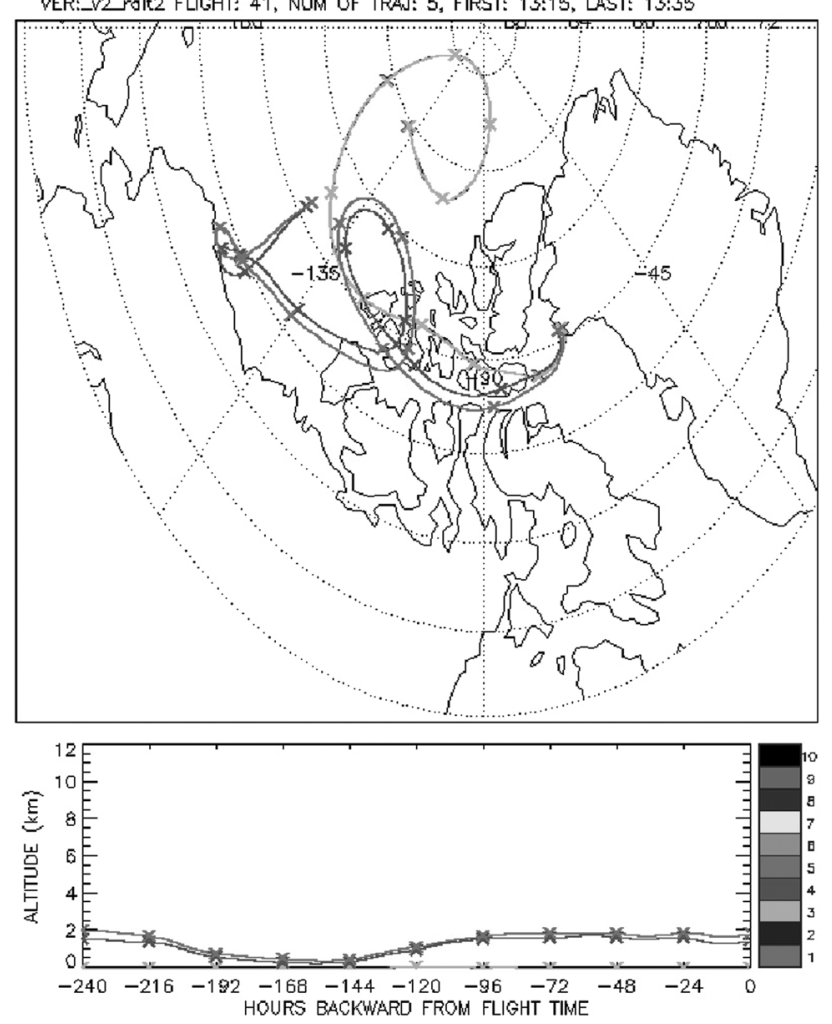

Figure 19. 10 day back-trajectories from North Baffin Bay/Thule region for the 22 May flight (Fight 41). See color version of this figure at back of this issue.

followed by transport down the channel separating Ellesmere Island from Greenland to Baffin Bay. It was not until 21 May that trajectories started to switch to sources from the west and the Arctic Ocean. Furthermore, a $30 \mathrm{~m}$ leg was also made over mid-Hudson Bay on this 22 May flight and no depletion was found. Trajectories for the Hudson Bay leg had mixed sources but not directly from the Arctic Ocean region. It is remarkable that the MODE could be transported such a long distance over reasonably rough topography.

\section{Summary}

[51] A qualitative characterization of surface ODEs as observed during TOPSE has been given. The flights have shown that ODEs can cover large areas over the Arctic and subarctic and can extend to over $2 \mathrm{~km}$ altitude. The flights have provided reasonably detailed characterization of vertical structure within and above ODEs. At least for the 2000 late winter through spring season, ODEs were uncommon at latitudes south of the Arctic Ocean. Although previous studies [Barrie and Platt, 1997] have emphasized formation of ODEs over the Arctic Ocean, it was a surprise to conclude from TOPSE that they seem to form only over the Arctic Ocean and therefore that some process unique to the ocean or its coastal regions remains unidentified. Accumulation of constituents in the frozen surface over the dark winter period cannot be the only prerequisite of ozone depletion since latitudes south of the Arctic Ocean which were investigated a number of times during these flights certainly would experience a long dark interval. The only case where an ODE might have formed distinct from the Arctic Ocean surface was a PODE found over Lancaster Sound on 4 April. Even in this case it may be that the small scale of the Sound was too restrictive to obtain reliable back-trajectories.

[52] We do not conclude that the Arctic Ocean region was extensively depleted throughout the spring period. A number of cases exist where the $30 \mathrm{~m}$ altitude legs encountered no ozone depletion but where trajectories did trace to the north and the Arctic Ocean. Examples are the low altitude legs shown in Figure $2 \mathrm{~b}$ of 21 and 23 February, 7 and 8 March, and 30 April. Of course it is possible in these cases that mixing processes during transport removed the ODE signature. It is also possible that there is a preferential region in the Arctic that triggers halogen activation. The flights also showed that no coarse surface feature such as solid ice/snow, open or refrozen leads, or polynyas correlated with the presence, absence, or intensity of ozone destruction.

[53] It was unique to find that ODEs can be transported long distances from the Arctic Ocean over reasonably smooth or rough topography and yet remain relatively intact. The slow photochemical production of ozone demonstrated from the measured $\mathrm{NO}$ and $\mathrm{RO}_{2}$ in ODEs at $30 \mathrm{~m}$ altitude would not be a limiting factor. Whether these exported ODEs also retained significant halogen activity is unclear from the observations presented here.

[54] It was also surprising to find only two cases of moderate pollution as measured by elevated $\mathrm{NO}_{\mathrm{y}}, \mathrm{PAN}$, or $\mathrm{CO}$ in the 32 flights within the surface layer. Such events were observed more frequently at higher altitudes (Atlas et al., submitted manuscript, 2002). Evidently there is no direct requirement for the presence of relatively fresh "pollution" sources or Arctic haze in ODEs [Barrie et al., 1998]. The rarity of pollution events at low altitude also implies that long-range transport to the Arctic most frequently undergoes lifting above the surface layer [Klonecki et al., 2002].

[55] Although a large suite of measurements have been described for the ODEs, we must admit, in the absence of on-board measurements of halogen radicals, that progress in understanding the initiation of or chemistry within ODEs was limited. TOPSE did provide in situ measurements of $\mathrm{OH}$ and $\mathrm{RO}_{2}$ in the Arctic surface layer. Steady state calculations of these radical concentrations without considering reactive halogen reactions were in reasonable agreement with or larger than observed for the early spring season. For a case examined in late May the measured concentrations were larger than calculated implying sources of radicals that were not measured during the flights or considered in the model. The measurement/model comparison was not precise enough to ascertain for the $30 \mathrm{~m}$ altitude the significance of sources of HONO, and hence $\mathrm{OH}$, from the snow surface as have been reported by Zhou et al. [2001], Dibb et al. [2002], and Honrath et al. [2002] at Alert or Summit, Greenland. From the $\mathrm{RO}_{2}$ and $\mathrm{NO}$ measurements in the surface layer, local $\mathrm{O}_{3}$ production rates were very small in early spring. By 22 May, the rate had increased by a factor of $10-1.5 \mathrm{ppbv} / \mathrm{d}$.

[56] The aircraft observations were consistent with a snow/ice source of formaldehyde although it is not clear 
how such sources are mixed to higher altitudes in cases where the surface layer stability was very high. In contrast, $\mathrm{NO}_{\mathrm{x}}$ from the sunlit surface source was reduced considerably by $30 \mathrm{~m}$ altitude. Arctic $\mathrm{NO}_{\mathrm{x}}$ at $30 \mathrm{~m}$ was smaller (median $\sim 15 \mathrm{pptv}$ ) than mixing ratios reported for $5 \mathrm{~m}$ or lower altitude at Alert [Ridley et al., 2000; Beine et al., 2002] and much smaller than the very high mixing ratios of NO reported for the surface layer of the Antarctic in late spring where insolation was continuously high [Davis et al., 2001]. In the Arctic when insolation was continuous and the elevation angle larger than $\sim 20^{\circ} \mathrm{NO}_{\mathrm{x}}$ tended to be smaller in PODEs which is consistent with formation and deposition of $\mathrm{BrONO}_{2}$ and/or $\mathrm{HNO}_{4}$. In MODEs, $\mathrm{NO}_{\mathrm{x}}$ tended to be larger but comparable to the median NODE abundance because formation of $\mathrm{BrONO}_{2}$ and $\mathrm{HNO}_{4}$ would be reduced because of the decreased partitioning of $\mathrm{NO}_{\mathrm{x}}$ to $\mathrm{NO}_{2}$ [Ridley and Orlando, 2002]. $\mathrm{HNO}_{3}$ and $\mathrm{HOOH}$ were typically small, $\sim 25$ pptv or less, in major ODEs. In agreement with previous studies made at the surface, PAN was by far the dominant reactive nitrogen constituent in the surface layer. Median PAN/NO fractions were $0.70-0.82$ for NODE to MODE conditions.

[57] Acknowledgments. We thank all of the personnel of the Research Aviation Facility at NCAR for providing the C130 aircraft and for the extra effort required at Churchill where no hangar was available, the National Science Foundation for support of TOPSE, K. Anlauf of the Meteorological Service of Canada for information on ozone at the Alert ground site, and J. Orlando for valuable discussion. NCAR is operated by the University Corporation for Atmospheric Research under sponsorship of the National Science Foundation.

\section{References}

Anlauf, K. G., R. E. Mickle, and N. B. A. Trivett, Measurement of ozone during Polar Sunrise Experiment 1992, J. Geophys. Res., 99, 25,34525,353, 1994.

Ariya, P. A., J. F. Hopper, and G. W. Harris, C2-C7 hydrocarbon concentrations in Arctic snowpack interstitial air: Potential presence of active $\mathrm{Br}$ within the snowpack, J. Atmos. Chem., 34, 55-64, 1999.

Barrie, L. A., Arctic air pollution: An overview of current knowledge, Atmos. Environ., 20, 643-663, 1986.

Barrie, L. A., and U. Platt, Arctic tropospheric chemistry: An overview, Tellus, 49B, 450-454, 1997.

Barrie, L. A., J. W. Bottenheim, R. C. Schnell, P. J. Crutzen, and R. A. Rasmussen, Ozone destruction and photochemical reactions at polar sunrise in the lower Arctic atmosphere, Nature, 334, 138-141, 1988.

Barrie, L. A., U. Platt, and P. Shepson, Surface ozone depletion at polar sunrise fueled by sea-salt halogens, IGACtivities Newsl., Int. Glob. Atmos. Chem. Project 14, pp. 4-7, Sept. 1998

Beine, H. J., D. A. Jaffe, F. Stordal, M. Engardt, S. Solberg, N. Schmidbauer, and $\mathrm{K}$. Holmén, $\mathrm{NO}_{\mathrm{x}}$ during ozone depletion events in the Arctic troposphere at Ny-Alesund, Svalbard, Tellus, 49B, 556-565, 1997.

Beine, H. J., R. E. Honrath, F. Dominé, W. R. Simpson, and J. D. Fuentes, $\mathrm{NO}_{\mathrm{x}}$ during background and ozone depletion periods at Alert: Fluxes above the snow surface, J. Geophys Res., 107(D21), 4584, doi:10.1029/ 2002JD002082, 2002.

Blake, N. J., D. R. Blake, B. C. Sive, A. S. Katzenstein, S. M. Meinardi, O. W. Wingenter, and F. S. Rowland, The seasonal evolution of NMHCs, light alkyl nitrates and selected halocarbons at mid to high northern latitudes during TOPSE, J. Geophys. Res., 108, doi:10.1029/ 2001JD001467, in press, 2002.

Bottenheim, J. W., A. C. Gallant, and K. A. Brice, Measurements of $\mathrm{NO}_{\mathrm{y}}$ species and $\mathrm{O}_{3}$ at $82^{\circ} \mathrm{N}$ latitude, Geophys. Res. Lett., 13, 113-116, 1986.

Bottenheim, J. W., L. A. Barrie, E. Atlas, L. E. Heidt, H. Niki, R. A. Rasmussen, and P. B. Shepson, Depletion of lower tropospheric ozone during Arctic spring: The Polar Sunrise Experiment 1988, J. Geophys. Res., 95, 18,555-18,568, 1990.

Bottenheim, J. W., L. A. Barrie, and E. Atlas, The partitioning of nitrogen oxides in the lower Arctic troposphere during spring 1988, J. Atmos. Chem., 17, 15-27, 1993.
Boudries, H., and J. W. Bottenheim, $\mathrm{Cl}$ and $\mathrm{Br}$ atom concentrations during a surface boundary layer ozone depletion event in the Canadian high Arctic, Geophys. Res. Lett., 27, 517-520, 2000.

Browell, E. V., et al., Ozone, aerosol, potential vorticity, and trace gas trends observed at high- latitudes over North America from February to May 2000, J. Geophys. Res., 108, doi:10.1029/2001JD001390, in press, 2002.

Cantrell, C., et al., Steady state free radical budgets and ozone photochemistry during TOPSE, J. Geophys. Res., 108, doi:10.1029/2002JD002198, in press, 2002.

Couch, T. L., A. L. Sumner, T. M. Dassau, P. B. Shepson, and R. E. Honrath, An investigation of the interaction of carbonyl compounds with the snowpack, Geophys. Res. Lett., 27, 2241-2244, 2000.

Davis, D., et al., Unexpected high levels of NO observed at South Pole, Geophys. Res. Lett., 28, 3625-3628, 2001.

de Serves, C., Gas phase formaldehyde and peroxide measurements in the Arctic atmosphere, J. Geophys. Res., 99, 25,391-25,398, 1994.

Dibb, J. E., R. W. Talbot, J. W. Munger, D. J. Jacob, and S.-M. Fan, Airsnow exchange of $\mathrm{HNO}_{3}$ and $\mathrm{NO}_{\mathrm{y}}$ at Summit, Greenland, J. Geophys. Res., 103, 3475-3486, 1998 .

Dibb, J. E., M. Arsenault, M. C. Peterson, and R. E. Honrath, Fast nitrogen oxide photochemistry in Summit, Greenland snow, Atmos. Environ., 36, 2801-2811, 2002.

Fan, S.-M., and D. J. Jacob, Surface ozone depletion in Arctic spring sustained by bromine reactions on aerosols, Nature, 359, 522-524, 1992.

Finlayson-Pitts, B. J., F. E. Livingston, and H. N. Berko, Ozone destruction and bromine photochemistry at ground level in the Arctic spring, Nature, $343,622-624,1990$

Foster, K. L., R. A. Plastridge, J. W. Bottenheim, P. B. Shepson, J. Finlayson-Pitts, and C. W. Spicer, The role of $\mathrm{Br}_{2}$ and $\mathrm{BrCl}$ in surface ozone destruction at polar sunrise, Science, 291, 471-474, 2001.

Hausmann, M., and U. Platt, Spectroscopic measurement of bromine oxide in the high Arctic during Polar Sunrise Experiment 1992, J. Geophys. Res., 99, 25,399-25,413, 1994.

Hebestreit, K., J. Stutz, D. Rosen, V. Matveiv, M. Peleg, M. Luria, and U. Platt, DOAS measurements of tropospheric bromine oxide in midlatitudes, Science, 283, 55-57, 1999.

Honrath, R. E., M. C. Peterson, S. Guo, J. E. Dibb, P. B. Shepson, and B. Campbell, Evidence of $\mathrm{NO}_{\mathrm{x}}$ production within or upon ice particles in the Greenland snowpack, Geophys. Res. Lett., 26, 695-698, 1999.

Honrath, R. E., M. C. Peterson, M. P. Dziobak, J. E. Dibb, M. A. Arsenault, and S. A. Green, Release of $\mathrm{NO}_{\mathrm{x}}$ from sunlight-irradiated midlatitude snow, Geophys. Res. Lett., 27, 2237-2240, 2000a.

Honrath, R. E., S. Guo, M. C. Peterson, M. P. Dziobak, J. E. Dibb, and M. A. Arsenault, Photochemical production of gas phase $\mathrm{NO}_{\mathrm{x}}$ from ice crystal $\mathrm{NO}_{3}^{-}$, J. Geophys. Res., 105, 24,183-24,190, $2000 \mathrm{~b}$.

Honrath, R. E., M. C. Peterson, Y. Lu, J. E. Dibb, M. A. Arsenault, N. J. Cullen, and K. Steffen, Vertical fluxes of $\mathrm{NO}_{x}, \mathrm{HONO}$ and $\mathrm{HNO}_{3}$ above the snowpack at Summit, Greenland, Atmos. Environ, 36, 2629-2640, 2002.

Hopper, J. F., L. A. Barrie, A. Silis, W. Hart, J. A. Gallant, and H. Dryfhout, Ozone and meteorology during the 1994 Polar Sunrise Experiment, J. Geophys. Res., 103, 1481-1492, 1998.

Impey, G. A., P. B. Shepson, D. R. Hastie, L. A. Barrie, and K. G. Anlauf, Measurements of photolyzable chlorine and bromine sources during Polar Sunrise Experiment 1995, J. Geophys. Res., 102, 16,005-16,010, 1997.

Impey, G. A., C. M. Mihele, K. G. Anlauf, L. A. Barrie, D. R. Hastie, and P. B. Shepson, Measurements of photolyzable halogen compounds and bromine radicals during the Polar Sunrise Experiment 1997, J. Atmos. Chem., 34, 21-37, 1999.

Jaeschke, W., T. Salkowski, J. P. Dierssen, J. V. Trümach, U. Krischke, and A. Günther, Measurements of trace substances in the Arctic troposphere as potential precursors and constituents of Arctic haze, J. Atmos. Chem., 34, 291-319, 1999.

Jobson, B. T., H. Niki, Y. Yokouchi, J. Bottenheim, F. Hopper, and R. Leaitch, Measurements of $\mathrm{C}_{2}-\mathrm{C}_{6}$ hydrocarbons during the 1992 Polar Sunrise Experiment: Evidence of Cl-atom and Br-atom chemistry, J. Geophys. Res., 99, 25,355-25,368, 1994.

Jones, A. E., R. Weller, E. W. Wolff, and H.-W. Jacobi, Speciation and rate of photochemical NO and $\mathrm{NO}_{2}$ production in Antarctic snow, Geophys. Res. Lett., 27, 345-348, 2000.

Klonecki, A., P. Hess, and D. Blake, Seasonal changes in the transport of pollutants into the Arctic troposphere: A model study, J. Geophys. Res., 107, doi:10.1029/2001JD002199, in press, 2002.

Kreher, K., P. V. Johnston, S. W. Wood, B. Nardi, and U. Platt, Groundbased measurements of tropospheric and stratospheric BrO at Arrival Heights, Antarctica, Geophys. Res. Lett., 24, 3021-3024, 1997.

Leaitch, W. R., L. A. Barrie, J. W. Bottenheim, S.-M. Li, P. B. Shepson, K. Muthuramu, and Y. Yokouchi, Airborne observations related to ozone depletion at polar sunrise, J. Geophys. Res., 99, 25,499-25,517, 1994. 
Le Bras, G., and U. Platt, A possible mechanism for combined chlorine and bromine catalyzed destruction of tropospheric ozone in the Arctic, Geophys. Res. Lett., 22, 599-602, 1995.

Lehrer, E., D. Wagenbach, and U. Platt, Chemical aerosol composition during tropospheric ozone depletion at Ny-Ålesund/Svalbard, Tellus, 49B, 486-495, 1997.

Matveev, V., M. Peleg, D. Rosen, D. Siman Tov-Alper, K. Hebestreit, J. Stutz, U. Platt, D. Blake, and M. Luria, Bromine oxide-ozone interaction over the Dead Sea, J. Geophys. Res., 106, 10,375-10,387, 2001.

McConnell, J. C., G. S. Henderson, L. A. Barrie, J. Bottenheim, H. Niki, C. H. Langford, and E. M. Templeton, Photochemical bromine production implicated in Arctic boundary-layer ozone depletion, Nature, 355, $150-152,1992$.

McElroy, C. T., C. A. McLinden, and J. C. McConnell, Evidence for bromine monoxide in the free troposphere during the Arctic Polar Sunrise, Nature, 397, 338-341, 1999.

Michalowski, B. A., J. S. Francisco, S.-M. Li, L. A. Barrie, J. W. Bottenheim, and P. B. Shepson, A computer model study of multiphase chemistry in the Arctic boundary layer during polar sunrise, J. Geophys. Res., $105,15,131-15,145,2000$.

Mozurkewich, M., Mechanisms for the release of halogens from sea-salt particles by free radical reactions, J. Geophys. Res., 100, 14,199-14,207, 1995.

Munger, J. W., D. J. Jacob, S.-M. Fan, A. S. Colman, and J. E. Dibb, Concentrations and snow-atmosphere fluxes of reactive nitrogen at Summit, Greenland, J. Geophys. Res., 104, 13,721-13,734, 1999.

Muthuramu, K., P. B. Shepson, J. W. Bottenheim, B. T. Jobson, H. Niki, and K. G. Anlauf, Relationships between organic nitrates and surface ozone destruction during Polar Sunrise Experiment 1992, J. Geophys. Res., 99, 25,369-25,378, 1994.

Oltmans, S. J., and W. D. Komhyr, Surface ozone distributions and variations from 1973-1984 measurements at the NOAA Geophysical Monitoring for Climatic Change baseline observatories, J. Geophys. Res., 91, 5229-5236, 1986.

Oum, K. W., M. J. Lakin, and B. J. Finlayson-Pitts, Bromine activation in the troposphere by the dark reaction of $\mathrm{O}_{3}$ with seawater ice, Geophys. Res. Lett., 25, 3923-3926, 1998.

Perner, D., T. Arnold, J. Crowley, T. Klüppel, M. Martinez, and R. Seuwen, The measurement of active chlorine in the atmosphere by chemical amplification, J. Atmos. Chem., 34, 9-20, 1999.

Platt, U., and E. Lehrer, Arctic troposphere halogen chemistry, Final Report to the European Community, ARCTOC, EVSV-CT93-0318, 1996.

Platt, U., and G. K. Moortgat, Heterogeneous and homogeneous chemistry of reactive halogen compounds in the lower troposphere, J. Atmos. Chem., 34, 1-8, 1999.

Ramacher, B., J. Rudolph, and R. Koppmann, Hydrocarbon measurements during tropospheric ozone depletion events: Evidence for halogen atom chemistry, J. Geophys. Res., 104, 3633-3653, 1999.

Richter, A., F. Wittrock, M. Eisinger, and J. P. Burrows, GOME observations of tropospheric BrO in northern hemispheric spring and summer 1997, Geophys. Res. Lett., 25, 2683-2686, 1998.

Ridley, B. A., and J. J. Orlando, Active nitrogen in surface ozone depletion events at Alert during spring 1998, J. Atmos. Chem., in press, 2002.

Ridley, B. A., et al., Is the Arctic surface layer a source and sink of $\mathrm{NO}_{\mathrm{x}}$ in winter/spring?, J. Atmos. Chem., 36, 1-22, 2000.

Rudolph, J., B. R. Fu, A. Thompson, K. Anlauf, and J. Bottenheim, Halogen atom concentrations in the Arctic troposphere derived from hydrocarbon measurements: Impact on the budget of formaldehyde, Geophys. Res. Lett., 26, 2941-2944, 1999.

Sander, R., R. Vogt, G. W. Harris, and P. J. Crutzen, Modeling the chemistry of ozone, halogen compounds, and hydrocarbons in the Arctic troposphere during spring, Tellus, 49B, 522-532, 1997.

Shepson, P. B., A.-P. Sirju, J. F. Hopper, L. A. Barrie, V. Young, H. Niki, and H. Dryfhout, Sources and sinks of carbonyl compounds in the Arctic Ocean boundary layer: Polar Ice Floe Experiment, J. Geophys. Res., 101, 21,081-21,089, 1996.
Snow, J., B. Heikes, J. Merrill, J. Moody, T. Wimmers, A. Fried, and C. Cantrell, Winter-spring evolution and variability of HOx reservoir species, hydrogen peroxide, methyl hydrogen peroxide and formaldehyde in northern mid- to high latitudes, J. Geophys. Res., 107, doi:10.1029/ 2001JD002172, in press, 2002.

Solberg, S., N. Schmidbauer, A. Semb, F. Stordal, and Ø. Hov, Boundary layer ozone depletion as seen in the Norwegian Arctic in spring, J. Atmos. Chem., 23, 301-332, 1996.

Staebler, R. M., G. den Hartog, B. Georgi, and T. Düsterdiek, Aerosol size distributions in Arctic haze during the Polar Sunrise Experiment 1992, J. Geophys. Res., 99, 25,429-25,438, 1994.

Stroud, V., E. Atlas, F. Flocke, B. Ridley, J. Walega, D. Montzka, and J. Bottenheim, Organic trace gases at Alert, NWT, during Polar Sunrise Experiment, 1998, Eos Trans. AGU, 79(45), F97, 1998.

Sumner, A. L., and P. B. Shepson, Snowpack production of formaldehyde and its effect on the Arctic troposphere, Nature, 398, 230-233, 1999.

Talbot, R. W., et al., Large-scale distributions of tropospheric nitric, formic, and acetic acids over the western Pacific basin during wintertime, J. Geophys. Res., 102, 28,303-28,313, 1997.

Tang, T., and J. C. McConnell, Autocatalytic release of bromine from Arctic snow pack during polar sunrise, Geophys. Res. Lett., 23, $2633-$ 2636, 1996.

Tuckermann, M., R. Ackermann, C. Gölz, H. Lorenzen-Schmidt, T. Seine, J. Stutz, B. Trost, W. Unold, and U. Platt, DOAS-observation of halogen radical-catalysed Arctic boundary layer ozone destruction during the ARCTOC-campaigns 1995 and 1996 in Ny-Ålesund, Spitsbergen, Tellus, 49B, 533-535, 1997.

Wagner, T., and U. Platt, Satellite mapping of enhanced BrO concentrations in the troposphere, Nature, 395, 486-490, 1998.

Weller, R., A. Minikin, G. König-Langlo, O. Schrems, A. E. Jones, E. W. Wolff, and P. S. Anderson, Investigating possible causes of the observed diurnal variability in Antarctic $\mathrm{NO}_{\mathrm{y}}$, Geophys. Res. Lett., 26, 2853-2856, 1999.

Wessel, S., S. Aoki, P. Winkler, R. Weller, A. Herber, and H. Gernandt, Tropospheric ozone depletion in polar regions: A comparison of observations in the Arctic and Antarctic, Tellus, 50B, 34-50, 1998.

Worthy, D. E. J., N. B. A. Trivett, J. F. Hopper, and J. W. Bottenheim, Analysis of long-range transport events at Alert, Northwest Territories, during the Polar Sunrise Experiment, J. Geophys. Res., 99, 25,32925,344, 1994.

Zhou, X., H. J. Beine, R. E. Honrath, J. D. Fuentes, W. Simpson, P. B. Shepson, and J. W. Bottenheim, Snowpack photochemical production of HONO: A major source of $\mathrm{OH}$ in the Arctic boundary layer in spring time, Geophys. Res. Lett., 28, 4087-4090, 2001.

E. L. Atlas, C. A. Cantrell, L. Cinquini, M. T. Coffey, L. K. Emmons, F. L. Eisele, F. M. Flocke, A. Fried, F. E. Grahek, J. W. Hannigan, B. L. Lefer, R. L. Mauldin, D. D. Montzka, B. A. Ridley, R. E. Shetter, J. G. Walega, A. J. Weinheimer, and B. P. Wert, Atmospheric Chemistry Division, National Center for Atmospheric Research, P.O. Box 3000, Boulder, CO 80307, USA. (ridley@acd.ucar.edu)

D. R. Blake and N. J. Blake, Department of Chemistry, University of California, Irvine, CA 92717, USA

E. V. Browell, R. J. DeYoung, W. B. Grant, and J. W. Hair, NASA Langley Research Center, Hampton, VA 23681, USA.

R. C. Cohen and J. A. Thornton, Department of Chemistry, University of California, Berkeley, CA 94720, USA.

J. E. Dibb and R. W. Talbot, Institute for the Study of Earth, Oceans and Space, University of New Hampshire, Durham, NH 03824, USA.

B. J. Heikes and J. A. Snow, Center for Atmospheric Chemical Studies, Graduate School of Oceanography, University of Rhode Island, Narragansett, RI 02882, USA.

J. L. Moody and A. J. Wimmers, Department of Environmental Sciences, University of Virginia, Charlottesville, VA 22903, USA. 

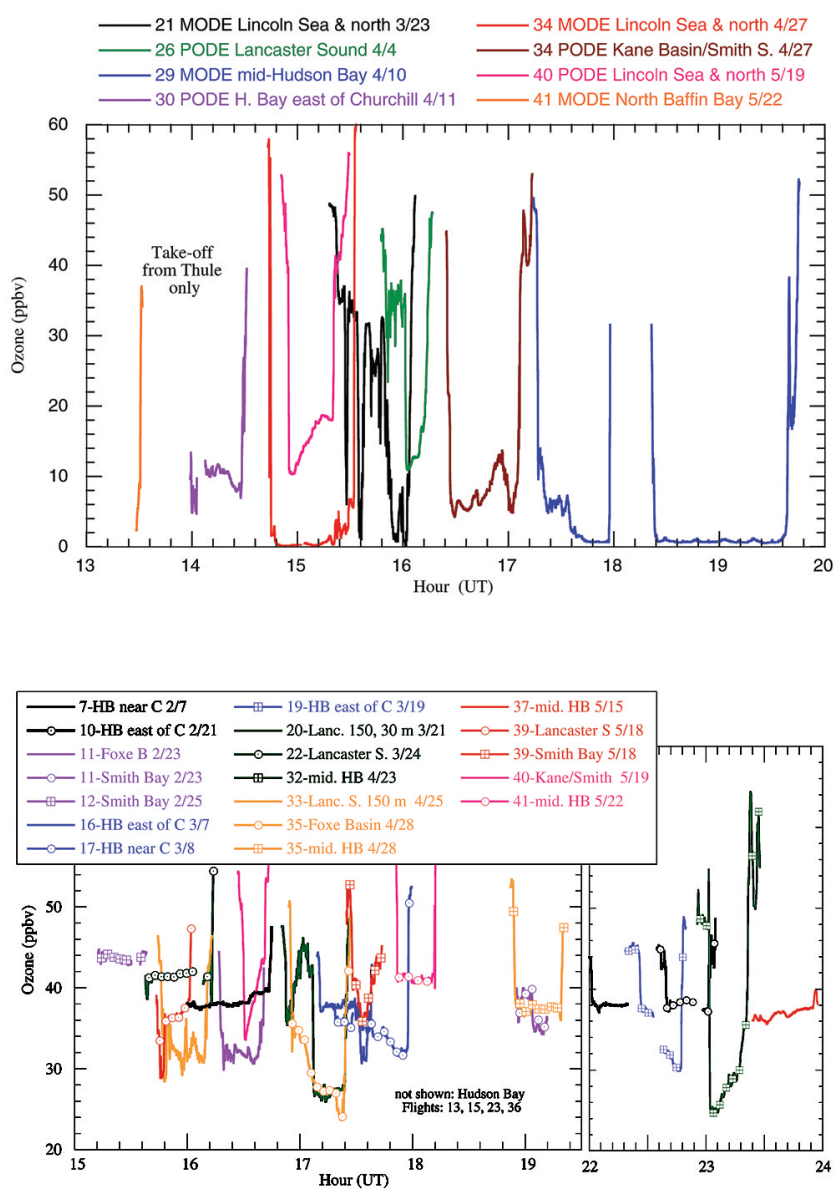

Figure 2. (a) Ozone mixing ratios for the ODEs encountered on low altitude flight legs within the surface layer. Most were at $30 \mathrm{~m}$ altitude but several were at $150 \mathrm{~m}$ altitude when visibility to lower altitudes was restricted. The vertical lines denote the gradient in ozone as the aircraft descended into or ascended from the low altitude flight leg. The locations are identified in Figure 1. (b) Ozone mixing ratios for most of the 24 low altitude flight legs where no clear ozone depletion was observed. The locations are identified in Figure 1. The legs are color coded from black to pink for increasing date. There is no obvious trend in ozone in these surface layer measurements from winter through spring.

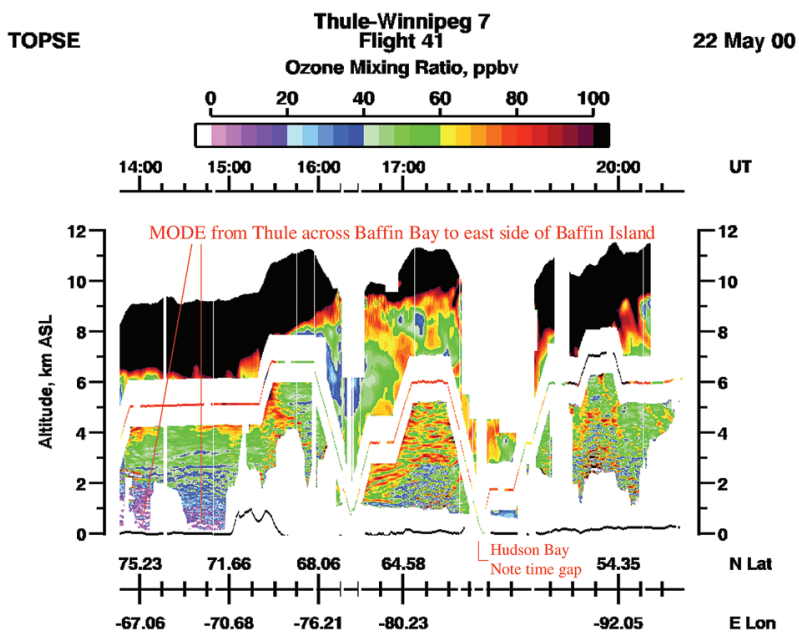

Figure 3. Zenith and nadir DIAL observations of ozone for Flight 41, 22 May from Thule Air Base to Winnipeg. Ozone was depleted from takeoff across Baffin Bay to the east side of Baffin Island, a distance of $600 \mathrm{~km}$, and to depths of $\sim 2.4$ $\mathrm{km}$. In the figure, the aircraft pressure altitude is denoted by the in situ ozone measurements, which are color coded as for the DIAL observations. Note that there is a gap in the DIAL data near 1730 UT when the aircraft descended for a low altitude leg over Hudson Bay. Higher ozone due to longrange transport from lower latitudes is also evident near 1700 UT between 2 and $6 \mathrm{~km}$ altitude. 

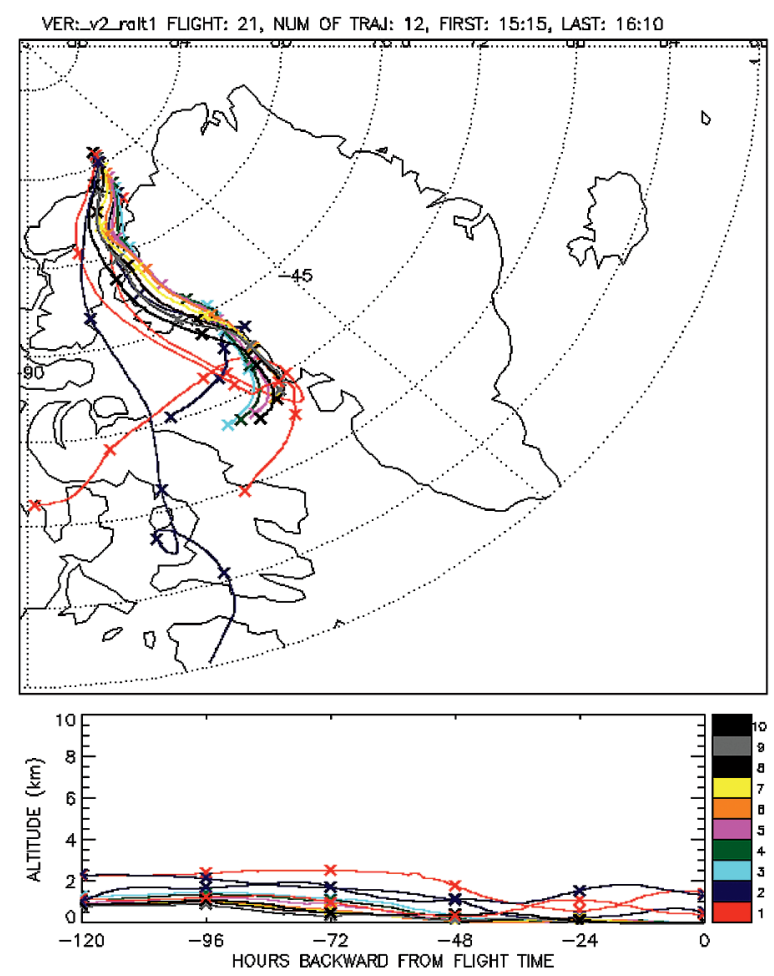

Figure 6. 5 day back-trajectories to the $30 \mathrm{~m}$ altitude leg and for final altitudes up to $1500 \mathrm{~m}$ for the 23 March flight corresponding to data shown in Figure 5.

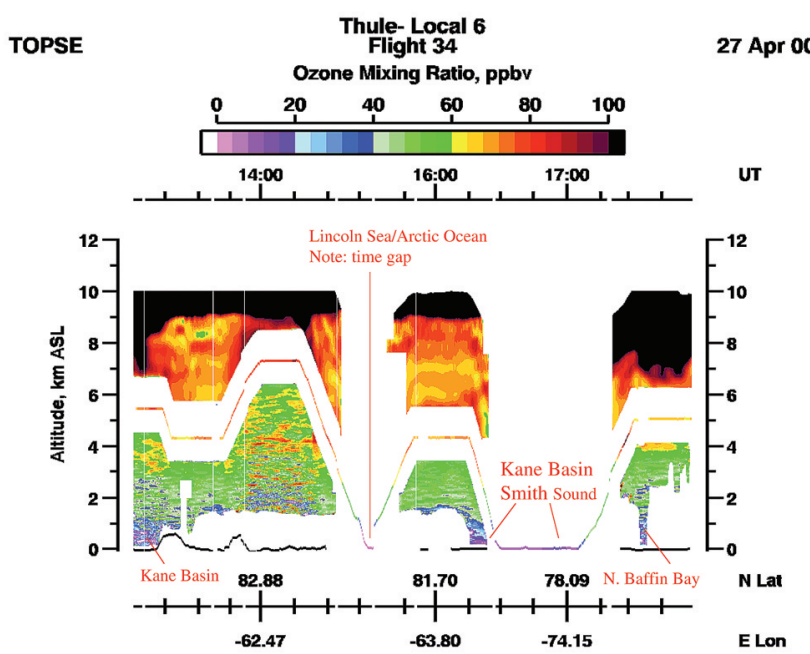

Figure 9. DIAL observations of ozone for the 27 April flight from Thule to the Arctic Ocean and return. Although clouds blocked the nadir view on much of the flight, ozone depletion was observed over Kane Basin on the north and south flight legs and also over N. Baffin Bay. Note the DIAL was off-line during much of the low altitude flight leg over the Arctic Ocean. 
RIDLEY ET AL.: SURFACE $\mathrm{O}_{3}$ DEPLETION EVENTS
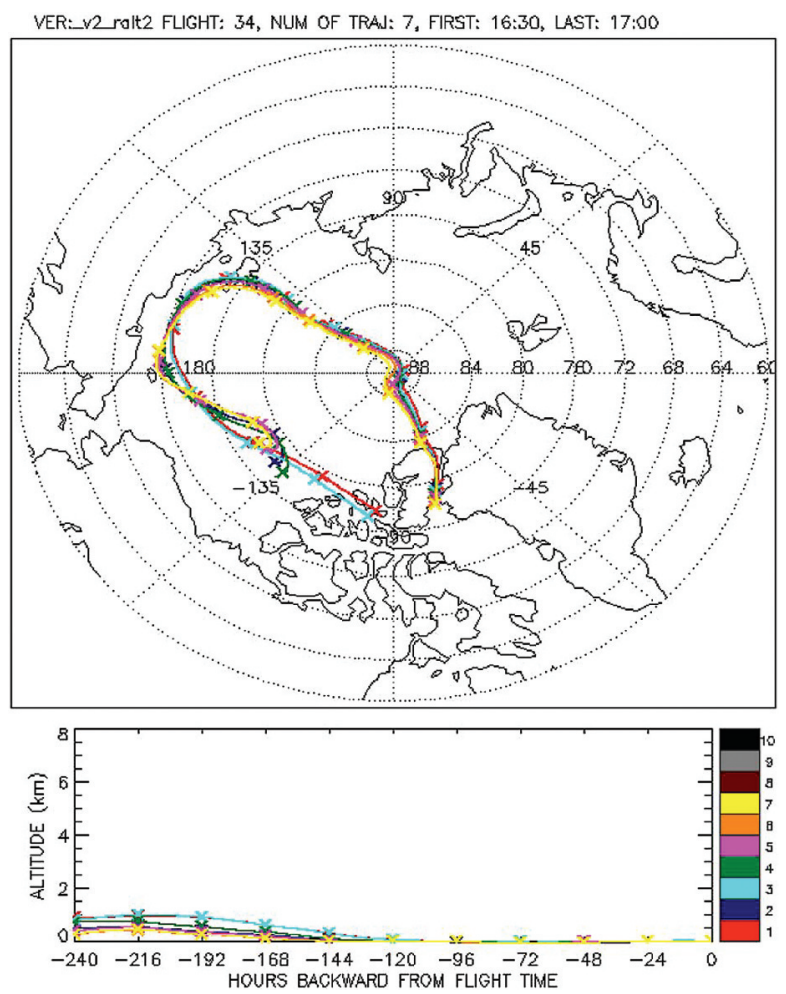

Figure 12. 10 day back-trajectories to the low altitude flight leg over Kane Basin and Smith Sound (lower panel of Figure 11) for the 27 April flight.

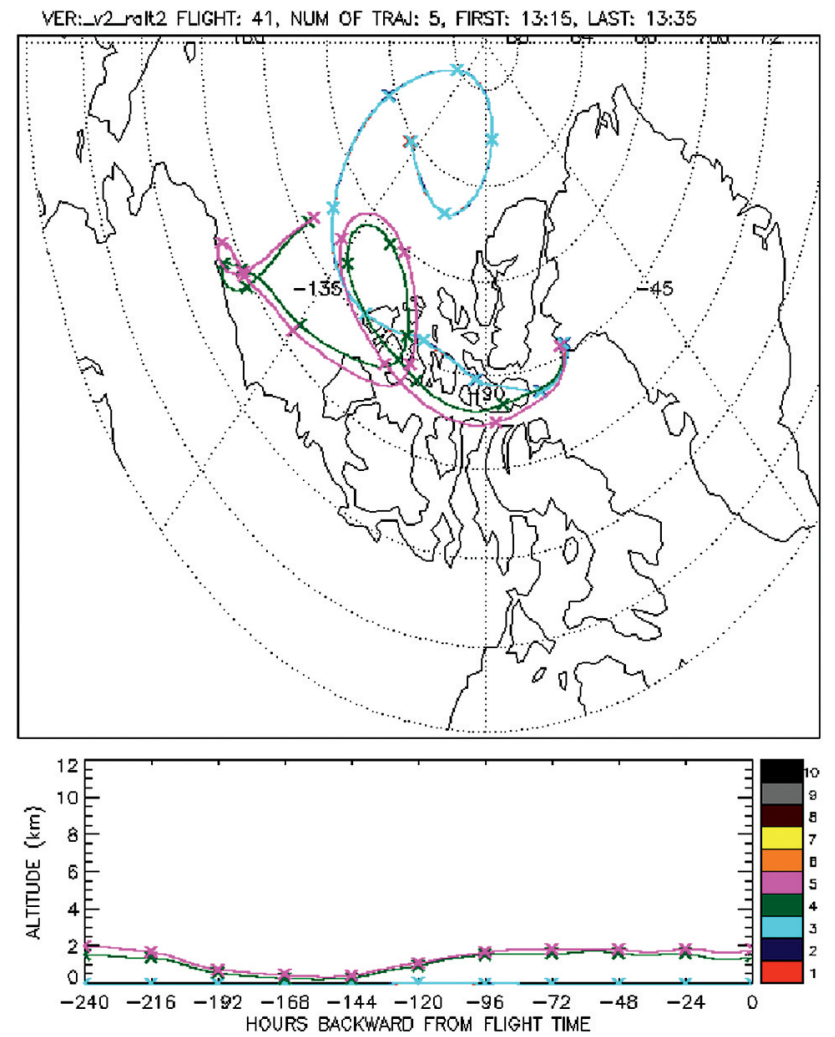

Figure 19. 10 day back-trajectories from North Baffin Bay/Thule region for the 22 May flight (Fight 41). 